\title{
Game-Theoretic Approach for Understanding and Modeling Clinical Pathways (Stable Ischemic Heart Disease)
}

Approved for public release. Distribution is unlimited.
Mark Pleszkoch Hilda B. Klasky Aneel Advani Edmon Begoli Aileen Boone Stephan Finn

October 2018 


\title{
DOCUMENT AVAILABILITY
}

Reports produced after January 1, 1996, are generally available free via US Department of Energy (DOE) SciTech Connect.

Website www.osti.gov

Reports produced before January 1, 1996, may be purchased by members of the public from the following source:

\author{
National Technical Information Service \\ 5285 Port Royal Road \\ Springfield, VA 22161 \\ Telephone 703-605-6000 (1-800-553-6847) \\ TDD 703-487-4639 \\ Fax 703-605-6900 \\ E-mail info@ntis.gov \\ Website http://classic.ntis.gov/
}

Reports are available to DOE employees, DOE contractors, Energy Technology Data Exchange representatives, and International Nuclear Information System representatives from the following source:

Office of Scientific and Technical Information

PO Box 62

Oak Ridge, TN 37831

Telephone 865-576-8401

Fax 865-576-5728

E-mail reports@osti.gov

Website http://www.osti.gov/contact.html

This report was prepared as an account of work sponsored by an agency of the United States Government. Neither the United States Government nor any agency thereof, nor any of their employees, makes any warranty, express or implied, or assumes any legal liability or responsibility for the accuracy, completeness, or usefulness of any information, apparatus, product, or process disclosed, or represents that its use would not infringe privately owned rights. Reference herein to any specific commercial product, process, or service by trade name, trademark, manufacturer, or otherwise, does not necessarily constitute or imply its endorsement, recommendation, or favoring by the United States Government or any agency thereof. The views and opinions of authors expressed herein do not necessarily state or reflect those of the United States Government or any agency thereof. 


\title{
GAME-THEORETIC APPROACH FOR UNDERSTANDING AND MODELING CLINICAL PATHWAYS (STABLE ISCHEMIC HEART DISEASE)
}

\author{
Mark Pleszcoch \\ Hilda B. Klasky \\ Aneel Advani \\ Edmon Begoli \\ Aileen Boone \\ Stephan Fihn
}

Date Published: October 2018

Prepared by

OAK RIDGE NATIONAL LABORATORY

Oak Ridge, TN 37831-6283

managed by

UT-BATTELLE, LLC

for the

US DEPARTMENT OF ENERGY

under contract DE-AC05-00OR22725 



\section{CONTENTS}

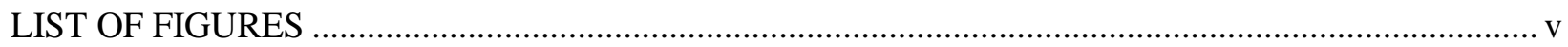

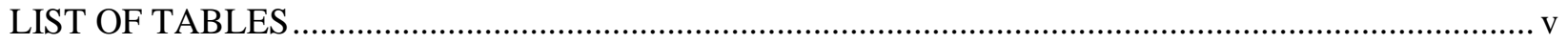

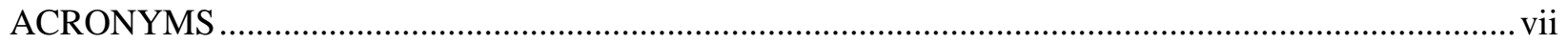

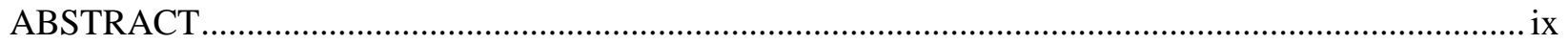

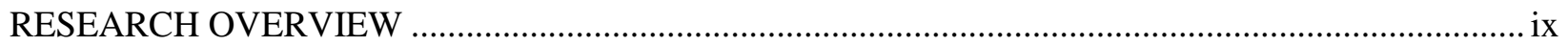

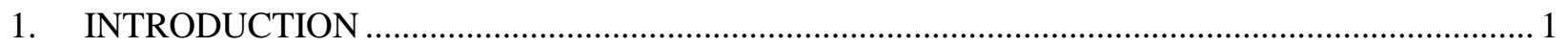

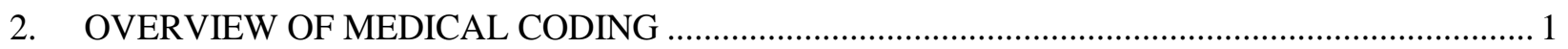

3. STABLE ISCHEMIC HEART DISEASE .................................................................... 7

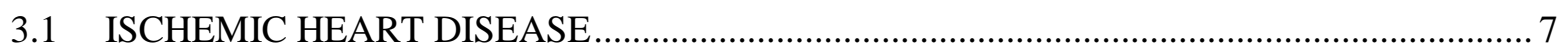

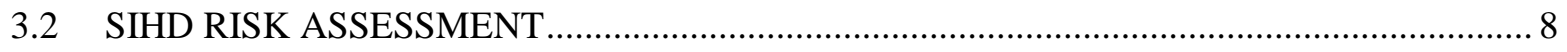

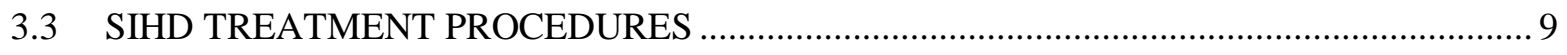

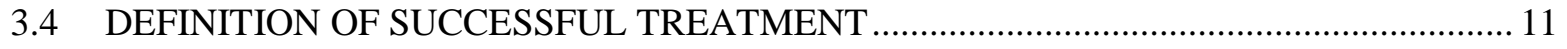

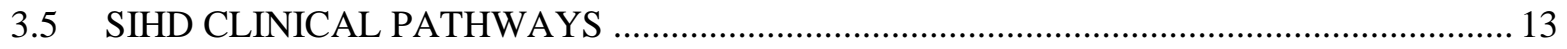

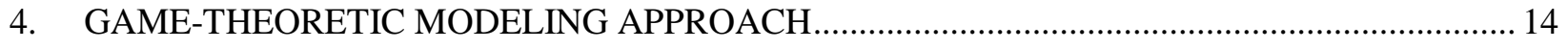

4.1 MOTIVATION FOR MODELING APPROACH ........................................................... 14

4.2 USING GAME THEORY AS A MATHEMATICAL MODEL ........................................... 15

4.3 STATISTICAL ANALYSIS OF GAME THEORY PARAMETERS ................................. 16

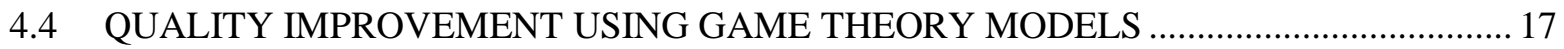

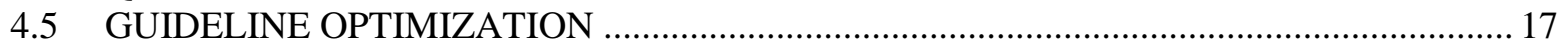

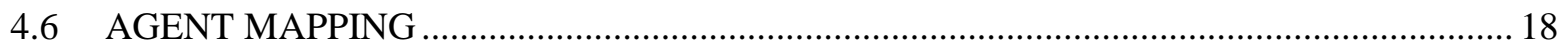

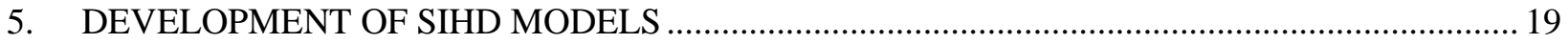

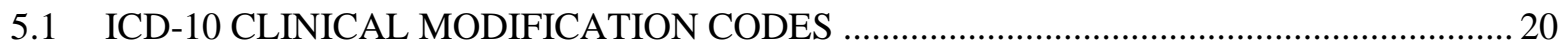

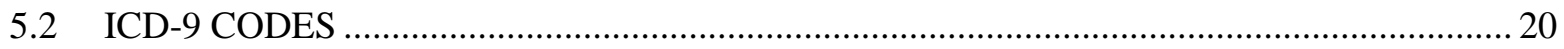

5.3 HIT-AA SIHD TARGET COHORTS FOR DATA ANALYSIS ...................................... 20

5.4 STRESS TEST SELECTION FOR SIHD DIAGNOSIS ................................................. 21

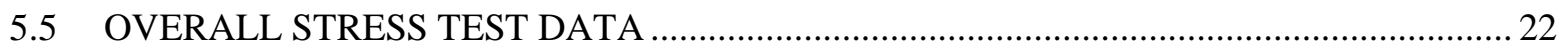

5.6 STRESS TEST DATA BY CONFOUNDING FACTOR …............................................. 22

5.7 PRELIMINARY RESULTS AND LESSONS LEARNED ................................................ 23

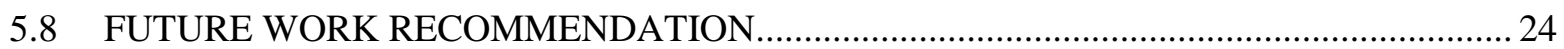

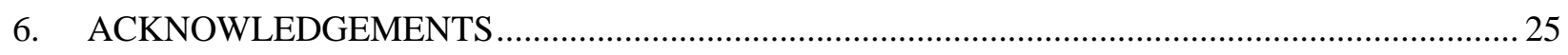

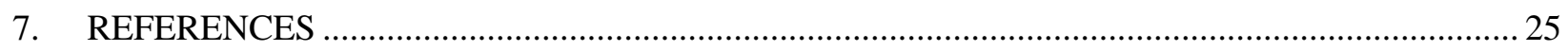

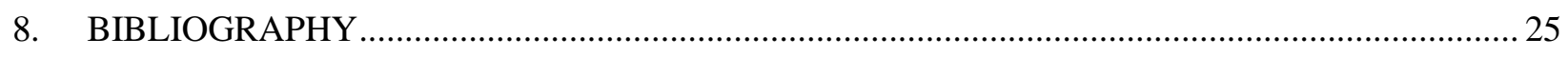

APPENDIX A. ICD-10 COMMON CARDIOVASCULAR DISEASE CODES ............................... A-1

APPENDIX B. FIGURES REDRAWN FROM THE 2012 ACCF GUIDELINE FOR SIHD ................ B-1

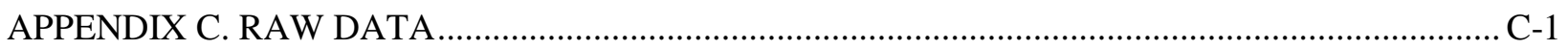





\section{LIST OF FIGURES}

Figure 1. Game theory as a formal model for patient response to clinical interventions.......................... 14

Figure 2. Definition of a Bayesian game from Manea (2016).......................................................... 16

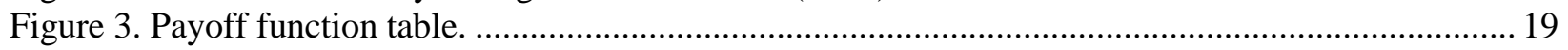

\section{LIST OF TABLES}

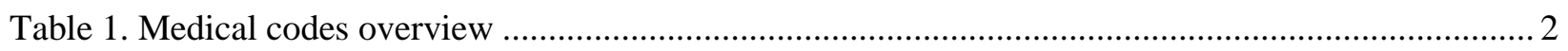

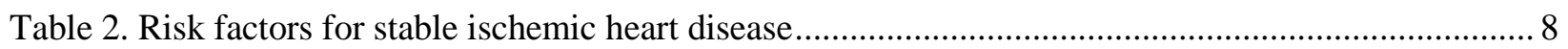

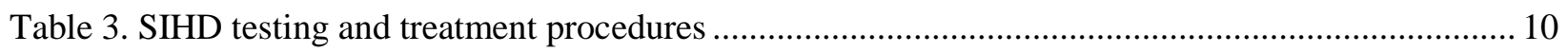

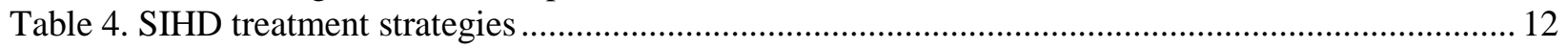

Table 5. Stress testing recommendations from the 2012 ACCF guideline ............................................ 15

Table 6. Mapping from Bayesian game theory to the clinical pathway for SIHD .................................... 16

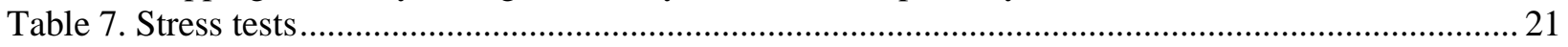

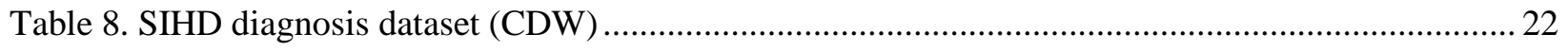

Table 9. SIHD diagnosis dataset arranged by confounding factor....................................................... 23 



\section{ACRONYMS}

$\mathrm{ACCF}$

ACE

ACS

AMA

AMI

ARB

BMS

BPMN

CABG

CCTA

CDC

CDT

CDW

CKD

CM

CMR

CMS

CPT

DES

DMII

E/M

ECG

EHR

FDA

HCPCS

HIT-AA

ICD

IHD

LV

MAC

MI

MPI

MS-DRG

NDC

NDF

$\mathrm{NIH}$

NLM

NSTEMI

ORNL

PAD

PCI

PCS

RXAUI

RXCUI

SIHD

STEMI

UA

UML
American College of Cardiology Foundation

angiotensin-converting enzyme (inhibitors)

acute coronary syndrome

American Medical Association

acute myocardial infarction

angiotensin II receptor blocker

bare metal stent

Business Process Modeling Notation

coronary artery bypass graft

computed coronary tomography angiography

Centers for Disease Control and Prevention

Code on Dental Procedures and Nomenclature

Corporate Data Warehouse

chronic kidney disease

clinical modification

cardiovascular magnetic resonance

Centers for Medicare \& Medicaid Services

Current Procedural Terminology

drug eluting stent

diabetes mellitus II

Evaluation and Management

electrocardiogram

electronic health record

Food and Drug Administration

Healthcare Common Procedure Coding System

Health Information Technology-Advanced Analytics

International Classification of Diseases

ischemic heart disease

liver

Medicare Administrative Contractor

myocardial infarction

myocardial perfusion imaging

Medicare Severity-Diagnosis Related Group

National Drug Code

National Drug File

National Institutes of Health

US National Library of Medicine

non-ST elevation myocardial infarction

Oak Ridge National Laboratory

peripheral artery disease

percutaneous coronary intervention

Procedure Coding System

RxNorm atom unique identifier

RxNorm concept unique identifier

stable ischemic heart disease

ST elevation myocardial infarction

unstable angina

Unified Modeling Language 
VA

US Department of Veterans Affairs

VHA Veterans Health Administration

WHO

World Health Organization 


\begin{abstract}
This research develops a game-theoretic agent model for stable ischemic heart disease (SIHD) clinical decisions, incorporating aspects of Bayesian game theory to model hidden information such as the patient's true underlying medical condition(s). Preexisting observational medical data contained in the United States Department of Veterans Affairs (VA) Corporate Data Warehouse (CDW) is analyzed to obtain the required game-theoretic parameter values. Various statistical adjustments are performed to correct for bias in the preexisting treatment protocol selections and to obtain game-theoretic parameter values for contrafactual treatment protocol choices. Once the game-theoretic parameter values are determined, clinical pathways can be viewed as being mathematical strategies for playing the game and thus can be studied and evaluated using the techniques of game theory.
\end{abstract}

\title{
RESEARCH OVERVIEW
}

Specific Aims: Our approach to understanding and modeling clinical pathways - in this case, for stable ischemic heart disease - has several advantages over the direct analysis of medical data for a particular treatment protocol. A key advantage derives from the ability to estimate the effect of alternative clinical interventions at any point in the interaction with a patient and not just the specific clinical intervention called for by the clinical pathway. For example, if the formal mathematical model obtained from our statistical analysis is implemented on a computer, the resulting program can be used to train new providers and assist with provider decision making, as well as be of use in patient education.

Also, by specializing the CDW data analysis to identified subcohorts, for example patients having a particular comorbidity, different variants of the game-theoretic parameter values are obtained. These can then be used to identify strategic inference trade-offs between individual patient optimality and general population optimality and to develop a scoring system (for metrics such as health improvement metrics, utilities, and costs) for agents and for games that is consistent with the optimizations and strategic inference tasks.

Significance: Providing a method to assess differences between patient optimality and cohort optimality can allow for more precise, tailored delivery of health care. Additionally, a scoring system for agents via health improvement metrics, utilities, and costs can further refine the model. This research could directly improve the quality of care as well as enable metrics regarding safety and value.

Innovation: Oak Ridge National Laboratory is providing a novel game-theoretic approach to a structured inference model for guideline-based clinical cohort analytics and quality measurement.

\section{Approach Taken:}

1. Adapt the mathematical formalism for Bayesian games to apply to the problem of modeling a patient's response to possible treatment protocols.

2. Analyze the CDW data to determine the specific values of the game-theoretic parameters.

3. Use the game-theoretic parameter values to determine the expected outcomes when applying a given clinical pathway, such as the 2012 American College of Cardiology Foundation clinical guideline for SIHD. 



\section{INTRODUCTION}

The Oak Ridge National Laboratory (ORNL) team describes herein our Health Information Technology Advanced Analytics (HIT-AA) game-theoretic approach to modeling the diagnosis and treatment of stable ischemic heart disease (SIHD). We begin in Section 2 with an overview of medical coding in general because a basic understanding of how medical coding works is essential to any approach to medical analysis. In Section 3, we describe our use case, SIHD, in detail and our mapping of SIHD risk factors, procedures, and outcomes to clinical codes (such as CPT, ICD-9, ICD-10, and NDF) and to the Corporate Data Warehouse (CDW) data. Section 4 defines and explains our game-theoretic approach to modeling medical use cases, contrasting our approach with prior work. As detailed below, we take a different approach to prior work, modeling the effects of clinical interventions on a patient as a formal mathematical model. Our novel approach provides several advantages that stem from the ability to estimate the effect of alternative clinical interventions at any point in the interaction with a patient and not just the specific clinical intervention called for by the clinical pathway. Section 4 also describes the problems we encountered with incomplete and/or incorrect CDW data. Finally, in Section 5 we provide a vision of how the results of game-theoretic analysis can be used in clinical pathway optimization.

\section{OVERVIEW OF MEDICAL CODING}

As an integral part of this research project, we needed to become familiar with medical codes; thus, we learned that each medical encounter has been assigned a predefined code for billing purposes and for use in health record systems. Medical codes play a very important role in our study and analysis; therefore, a

good understanding of the different codes is critical for our work. Table 1 provides a brief overview of the most common medical codes. The table columns present (1) the code set, (2) a brief definition of the code set, (3) the developer and maintainer of the code set, (4) a brief explanation of how the code set works in terms of its format and for billing, and (5) a link as reference for further information.

The codes used most commonly are Current Procedural Terminology (CPT) codes, which are used in insurance claims to pay for furnished services. Whatever CPT code is submitted for payment, at least one International Classification of Diseases - Clinical Modification (ICD-CM) code must be attached to support the reason for the encounter (office visit). There must be one or several ICD codes for every medical encounter. For example, if a physician is admitting a patient to the hospital, the physician could choose critical care Evaluation and Management (E/M) CPT code 99291. If the visit lasts longer than 74 minutes, the physician could also submit the add-on critical care code 99292.

As a hospitalist, if the physician sees patients for stroke, they would submit to insurance the ICD code 434.91 (cerebral artery occlusion, unspecified with cerebral infarction) attached to a CPT code. The CPT code s/he chooses would depend on the type of E/M service s/he provides. However, the CPTs and ICDs in the health record may not reflect the relationship expected from the encounter visit. For example, Trotter (2011) writes:

In addition, insurance billing codes bear no resemblance to reality. If a doctor needs to bill insurance for something and the list of billing codes doesn't happen to include exactly what the patient's condition is, they cram it into something else that the system will accept... Everyone is used to this system and none seem to care if things are making any sense. Nobody counts on the data to be meaningful in the first place.

During our analysis using CDW data, we found the latter surprising but real. Later, in this document, we present our findings of the data that several of our subject matter experts considered erroneous. 
Table 1. Medical codes overview

\begin{tabular}{|c|c|c|c|c|}
\hline Code set & Definition & Developer/maintainer & How it works & Reference link \\
\hline HCPCS & $\begin{array}{l}\text { Healthcare Common Procedure } \\
\text { Coding System (HCPCS, often } \\
\text { pronounced by its acronym as } \\
\text { "hick picks") is a set of health } \\
\text { care procedure codes based on } \\
\text { the American Medical } \\
\text { Association's (AMA's) Current } \\
\text { Procedural Terminology (CPT). } \\
\text { HCPCS is a medical billing } \\
\text { process used by the Centers for } \\
\text { Medicare \& Medicaid Services } \\
\text { (CMS). } \\
\text { HCPCS is divided into two } \\
\text { principal subsystems, referred to } \\
\text { as Level I and Level II of the } \\
\text { HCPCS. }\end{array}$ & CMS & $\begin{array}{l}\text { Coders today use HCPCS codes to } \\
\text { represent medical procedures to } \\
\text { Medicare, Medicaid, and several other } \\
\text { third-party payers. } \\
\text { The code set is divided into three levels. } \\
\text { Level I is identical to CPT, though } \\
\text { technically those codes, when used to bill } \\
\text { Medicare or Medicaid, are HCPCS } \\
\text { codes. } \\
\text { Level II refers to everything not covered } \\
\text { by Level I. } \\
\text { Level III has been deprecated and is not } \\
\text { discussed here. }\end{array}$ & $\frac{\text { https://www.aapc.com/resources/me }}{\underline{\text { dical-coding/hcpcs.aspx }}}$ \\
\hline $\begin{array}{l}\text { HCPCS Level } \\
\text { I codes = } \\
\text { CPT }\end{array}$ & $\begin{array}{l}\text { CPT (current version is CPT-4) } \\
\text { HCPCS Level I codes and } \\
\text { modifiers are the CPT codes. } \\
\text { They are a series of numbers } \\
\text { (usually } 5 \text { digits long) that are } \\
\text { used to identify medical services } \\
\text { and procedures performed by } \\
\text { physicians as well as for other } \\
\text { diagnostic services. They are a } \\
\text { language of communication with } \\
\text { third-party insurance payers. }\end{array}$ & AMA & $\begin{array}{l}\text { When providers report HCPCS codes on } \\
\text { claims, the Medicare Administrative } \\
\text { Contractor (MAC) uses the codes to } \\
\text { either determine coverage or the amount } \\
\text { CMS will pay for furnished services (less } \\
\text { beneficiary coinsurance and } \\
\text { copayments). } \\
\text { CPT codes are identified using } 5 \text { numeric } \\
\text { digits. }\end{array}$ & $\frac{\underline{\text { https://www.cms.gov/Medicare/Cod }}}{\underline{\text { ing/MedHCPCSGenInfo/HCPCS }}}$ \\
\hline
\end{tabular}


Table 1. Medical codes overview (continued)

\begin{tabular}{|c|c|c|c|c|}
\hline Code set & Definition & Developer/maintainer & How it works & Reference link \\
\hline $\begin{array}{l}\text { HCPCS Level } \\
\text { II codes }\end{array}$ & $\begin{array}{l}\text { HCPCS Level II codes and } \\
\text { modifiers primarily identify } \\
\text { products, supplies, and services } \\
\text { not included in the CPT codes } \\
\text { (such as ambulance services; } \\
\text { drugs; devices; and durable } \\
\text { medical equipment, prosthetics, } \\
\text { orthotics, and supplies) }\end{array}$ & CMS & $\begin{array}{l}\text { Level II codes are also referred to as alpha- } \\
\text { numeric codes because they consist of a } \\
\text { single alphabetical letter followed by } 4 \\
\text { numeric digits, while CPT codes are } \\
\text { identified using } 5 \text { numeric digits. } \\
\text { Types of HCPCS Level II codes: } \\
\text { 1. Permanent national codes } \\
\text { 2. Dental codes } \\
\text { 3. Miscellaneous codes } \\
\text { 4. Temporary national codes }\end{array}$ & https://coder.aapc.com/hcpcs-codes \\
\hline ICD & $\begin{array}{l}\text { International Classification of } \\
\text { Diseases (ICD) }\end{array}$ & $\begin{array}{l}\text { World Health } \\
\text { Organization (WHO) }\end{array}$ & $\begin{array}{l}\text { ICD is the foundation for the identification } \\
\text { of health trends and statistics globally } \\
\text { and the international standard for } \\
\text { reporting diseases and health conditions. } \\
\text { It is the diagnostic classification standard } \\
\text { for all clinical and research purposes. } \\
\text { ICD defines the universe of diseases, } \\
\text { disorders, injuries, and other related } \\
\text { health conditions listed in a } \\
\text { comprehensive, hierarchical fashion that } \\
\text { allows for } \\
\text { - easy storage, retrieval, and analysis of } \\
\text { health information for evidenced-based } \\
\text { decision-making; } \\
\text { - sharing and comparing health } \\
\text { information between hospitals, regions, } \\
\text { settings, and countries; and } \\
\text { - data comparisons in the same location } \\
\text { across different time periods. }\end{array}$ & $\begin{array}{l}\text { http://www.who.int/classifications/ic } \\
\underline{\mathrm{d} / \mathrm{en} /}\end{array}$ \\
\hline
\end{tabular}


Table 1. Medical codes overview (continued)

\begin{tabular}{|c|c|c|c|c|}
\hline Code set & Definition & Developer/maintainer & How it works & Reference link \\
\hline ICD-10-CM & $\begin{array}{l}\text { ICD-CM is a billing ontology. } \\
\text { CM stands for Clinical } \\
\text { Modification. }\end{array}$ & $\begin{array}{l}\text { Centers for Disease } \\
\text { Control and Prevention } \\
\text { (CDC) }\end{array}$ & $\begin{array}{l}\text { Inpatient providers report ICD-10-CM } \\
\text { diagnosis and ICD-10-PCS procedure } \\
\text { codes on claims, which MAC uses to } \\
\text { assign discharges to the appropriate } \\
\text { Medicare Severity-Diagnosis Related } \\
\text { Group (MS-DRG). } \\
\text { There must be an ICD code for every } \\
\text { medical encounter. } \\
\text { Whatever CPT code is submitted for } \\
\text { payment, at least one ICD code must be } \\
\text { attached to support the reason for the } \\
\text { encounter. }\end{array}$ & $\begin{array}{l}\text { https://www.cdc.gov/nchs/icd/icd10 } \\
\underline{\mathrm{cm} \cdot \mathrm{htm}}\end{array}$ \\
\hline ICD-10-PCS & $\begin{array}{l}\text { ICD-10 Procedure Coding System } \\
\text { (PCS) }\end{array}$ & CMS & $\begin{array}{l}\text { ICD-10-PCS has a 7-character } \\
\text { alphanumeric code structure. Each } \\
\text { character contains up to } 34 \text { possible } \\
\text { values. Each value represents a specific } \\
\text { option for the general character definition } \\
\text { (e.g., stomach is one of the values for the } \\
\text { body part character). The } 10 \text { digits } 0-9 \\
\text { and the } 24 \text { letters A-H, J-N, and P-Z may } \\
\text { be used in each character. The letters O } \\
\text { and I are not used in order to avoid } \\
\text { confusion with the digits } 0 \text { and } 1 .\end{array}$ & $\frac{\text { https://www.cms.gov/Medicare/Cod }}{\text { ing/ICD10/downloads/pcs_final_r }}$ \\
\hline ICD-9-CM & $\begin{array}{l}\text { International Classification of } \\
\text { Diseases, Ninth Revision, } \\
\text { Clinical Modification }\end{array}$ & CMS & $\begin{array}{l}\text { The ICD-9 was used to code and classify } \\
\text { mortality data from death certificates } \\
\text { until 1999, when use of ICD-10 for } \\
\text { mortality coding started. } \\
\text { The ICD-9-CM consists of } \\
\text { - a tabular list containing a numerical } \\
\text { list of the disease code numbers in } \\
\text { tabular form; } \\
\text { - an alphabetical index to the disease } \\
\text { entries; and } \\
\text { - a classification system for surgical, } \\
\text { diagnostic, and therapeutic procedures } \\
\text { (alphabetic index and tabular list). }\end{array}$ & $\frac{\text { https://www.cdc.gov/nchs/icd/icd9c }}{\underline{\text { m.htm }}}$ \\
\hline
\end{tabular}


Table 1. Medical codes overview (continued)

\begin{tabular}{|c|c|c|c|c|}
\hline Code set & Definition & Developer/maintainer & How it works & Reference link \\
\hline $\mathrm{NDF}$ & $\begin{array}{l}\text { US Department of Veterans Affairs } \\
\text { (VA) National Drug File (NDF) }\end{array}$ & $\begin{array}{l}\text { VA Veterans Health } \\
\text { Administration (VHA) }\end{array}$ & $\begin{array}{l}\text { The VA NDF is a centrally maintained } \\
\text { electronic drug list used by the VA } \\
\text { hospitals and clinics. Facilities use the } \\
\text { VA NDF to check drug interactions, to } \\
\text { manage orders, and to send outpatient } \\
\text { prescriptions to regional automated mail- } \\
\text { out pharmacies. The VA NDF includes } \\
\text { information on clinical drugs, drug } \\
\text { classes, ingredients, and National Drug } \\
\text { Code (NDC) directory codes. }\end{array}$ & $\frac{\frac{\text { www.pbm.va.gov }}{\text { https://www.data.va.gov/dataset/va- }}}{\underline{\text { national-drug-file }}}$ \\
\hline NDC & Drug database & $\begin{array}{l}\text { Registered drug } \\
\text { establishments provide } \\
\text { the Food and Drug } \\
\text { Administration (FDA) } \\
\text { with a current list of all } \\
\text { drugs manufactured, } \\
\text { prepared, propagated, } \\
\text { compounded, or } \\
\text { processed by it for } \\
\text { commercial distribution. }\end{array}$ & $\begin{array}{l}\text { Drug products are identified and reported } \\
\text { using a unique, } 3 \text {-segment number, called } \\
\text { the NDC, which serves as a universal } \\
\text { product identifier for drugs. }\end{array}$ & $\frac{\text { https://www.fda.gov/drugs/informati }}{\text { onondrugs/ucm142438.htm }}$ \\
\hline
\end{tabular}


Table 1. Medical codes overview (continued)

\begin{tabular}{|c|c|c|c|c|}
\hline Code set & Definition & Developer/maintainer & How it works & Reference link \\
\hline RxNorm & $\begin{array}{l}\text { RxNorm is two things: (1) a } \\
\text { normalized naming system for } \\
\text { generic and branded drugs and } \\
\text { (2) a tool for supporting semantic } \\
\text { interoperation between drug } \\
\text { terminologies and pharmacy } \\
\text { knowledge base systems. }\end{array}$ & $\begin{array}{l}\text { US National Library of } \\
\text { Medicine (NLM) at the } \\
\text { National Institutes of } \\
\text { Health (NIH) }\end{array}$ & $\begin{array}{l}\text { NLM receives drug names from many data } \\
\text { sources, analyzes and processes the data, } \\
\text { and outputs the data into RxNorm files in } \\
\text { a standard format. There are many steps } \\
\text { involved in RxNorm production, but } \\
\text { these five basic steps give a general idea } \\
\text { of how RxNorm is produced: } \\
\text { 1. Group source data into collections of } \\
\text { synonyms (called concepts). } \\
\text { 2. Create an RxNorm normalized name } \\
\text { for each concept (if the concept is in } \\
\text { scope and unambiguous). } \\
\text { 3. Assign an RxNorm concept unique } \\
\text { identifier (RXCUI) to each concept } \\
\text { and an RxNorm atom unique identifier } \\
\text { (RXAUI) to each atom. } \\
\text { 4. Include relationships and attributes } \\
\text { from the source data. } \\
\text { 5. Create related RxNorm names and } \\
\text { relationships. }\end{array}$ & $\frac{\text { https://www.nlm.nih.gov/research/u }}{\underline{\text { mls/rxnorm/overview.html }}}$ \\
\hline CDT & $\begin{array}{l}\text { Code on Dental Procedures and } \\
\text { Nomenclature (CDT code) }\end{array}$ & $\begin{array}{l}\text { American Dental } \\
\text { Association }\end{array}$ & $\begin{array}{l}\text { The purpose of the CDT code is to achieve } \\
\text { uniformity, consistency, and specificity } \\
\text { in accurately documenting dental } \\
\text { treatment. One use of the CDT code is to } \\
\text { provide for the efficient processing of } \\
\text { dental claims, and another is to populate } \\
\text { an electronic health record (EHR). } \\
\text { The CDT code entry is a 5-character } \\
\text { alphanumeric beginning with "D." The } \\
\text { CDT code entry also contains a name, } \\
\text { which is the title of the procedure and a } \\
\text { description that provides definition and } \\
\text { intended use of the procedures. }\end{array}$ & www.ada.org \\
\hline
\end{tabular}




\section{STABLE ISCHEMIC HEART DISEASE}

The HIT-AA team studied ischemic heart disease (IHD) to improve its understanding of the problem and relied heavily on the 2012 American College of Cardiology Foundation (ACCF) guideline (Fihn et al. 2012) for SIHD and VA subject matter expertise.

\subsection{ISCHEMIC HEART DISEASE}

IHD is widely known to be the primary cause of death in men. This is also true for women, accounting for $22.3 \%$ of deaths (compared with $21.1 \%$ due to cancer) (CDC 2015). IHD is a chronic disorder with a natural history spanning multiple decades within the individual, during which time there is a progressive buildup of plaque in one or more of the coronary arteries. As the blood flow path opening through the coronary arteries narrows, the disease typically progresses through clinically defined phases:

1. asymptomatic;

2. stable angina;

3. accelerating angina; and

4. acute coronary syndrome (ACS), which is either unstable angina (UA) or acute myocardial infarction (AMI) (Fihn et al. 2012).

However, the progression from one state to the next is not necessarily linear because a portion of plaque can break off from where it formed and create a blood flow blockage in another part of the body. As a rule of thumb, asymptomatic IHD corresponds to a blood flow narrowing, or stenosis, of $50 \%$ or less; stable angina corresponds to a stenosis of $70 \%$; and the later phases correspond to a stenosis of $80 \%$ or more (OnlineMedEd 2016).

Angina is a severe localized pain. A patient is said to have typical angina if s/he meets all the following criteria: (1) the pain is located in the substernal chest, (2) the pain is provoked by exertion or emotional stress, and (3) the pain is relieved by rest and/or nitroglycerin.

A well-accepted risk classification for cardiovascular events is the following:

1. patients with a predicted annual cardiac mortality rate of $<1 \%$ per year are considered to be at low risk,

2. patients with a predicted rate of $1 \%$ to $3 \%$ per year are considered to be at intermediate risk, and

3. patients with a predicted average $>3 \%$ per year are considered to be at high risk (Fihn et al. 2012).

For this study, we defined SIHD patients as those patients who have CDW records containing the ICD-10 $\operatorname{codes}^{1}$ I20, I21, I22, I23, I24, and I25, and containing the ICD-9 codes 410, 411, 412, 413, and 414 (see Appendix A).

In the following sections, we mapped risk factors, procedures, and outcomes from the 2012 ACCF/AHA/ACP/AATS/PCNA/SCAI/STS Guideline for the Diagnosis and Management of Patients with Stable Ischemic Heart Disease (Fihn et al. 2012) to CPT, ICD-9, ICD-10, and NDF codes.

${ }^{1}$ Source: https://www.icd10data.com/. 


\subsection{SIHD RISK ASSESSMENT}

Table 2 presents general considerations for risk assessment from the 2012 ACCF/AHA/ACP/AATS/PCNA/SCAI/STS Guideline for the Diagnosis and Management of Patients with Stable Ischemic Heart Disease (Fihn et al. 2012). The table maps SIHD risk factors to the clinical codes (CPT, ICD-9, ICD-10, NDF).

Table 2. Risk factors for stable ischemic heart disease

\begin{tabular}{|c|c|}
\hline Risk factor & Clinical code \\
\hline \multicolumn{2}{|c|}{ Sociodemographic characteristics } \\
\hline Age & N/A \\
\hline Ethnicity & N/A \\
\hline Sex & N/A \\
\hline Lower socioeconomic status & \begin{tabular}{|l|} 
ICD-10 CM: Z59.5 \\
2015 ICD-9-CM V60.2
\end{tabular} \\
\hline \multicolumn{2}{|r|}{ Cardiovascular } \\
\hline Smoking & \begin{tabular}{|l}
99406 \\
99407 \\
ICD-10-CM Diagnosis Code Z71.6 \\
2015 ICD-9-CM V65.42 \\
\end{tabular} \\
\hline Hyperlipidemia or dyslipidemia & $\begin{array}{l}\text { ICD-10 I10 to I16 (ICD-9 } 401 \text { to 405) } \\
\text { ICD-10 E78 (ICD-9 272) }\end{array}$ \\
\hline Diabetes mellitus & ICD-10: E08, E09, E10, E11, E13 \\
\hline Hypertension & $\begin{array}{l}\text { ICD-10-CM Diagnosis Code I10 } \\
2015 \text { ICD-9-CM 401.0 } \\
2015 \text { ICD-9-CM 401.1 } \\
2015 \text { ICD-9-CM 401.9 }\end{array}$ \\
\hline Obesity or metabolic syndrome & $\begin{array}{l}\text { ICD-10 E66 (ICD-9 270.0) } \\
\text { ICD-10 E88.81 (ICD-9 277.7) }\end{array}$ \\
\hline Physical inactivity & $\begin{array}{l}\text { Health and behavior, assessment: 96150-96155 } \\
\text { ICD-10-CM Diagnosis Code Z72.3 } \\
2015 \text { ICD-9-CM V69.0 }\end{array}$ \\
\hline $\begin{array}{l}\text { A family history of premature IHD (i.e., } \\
\text { onset in a father, brother, or son before } \\
\text { age } 55 \text { years or a mother, sister, or } \\
\text { daughter before age } 65 \text { years) }\end{array}$ & $\begin{array}{l}\text { ICD-10 Z82.49 code for family history } \\
\text { 2015 ICD-9 V17.49 }\end{array}$ \\
\hline $\begin{array}{l}\text { A history of cerebrovascular or } \\
\text { peripheral artery disease (PAD)—also } \\
\text { increases likelihood of IHD }\end{array}$ & $\begin{array}{l}\text { ICD-10 CM: I73.9 } \\
\text { 2015 ICD-9-CM } 443.9\end{array}$ \\
\hline \multicolumn{2}{|c|}{$\begin{array}{l}\text { Coexisting medical conditions } \\
\end{array}$} \\
\hline Diabetes mellitus & $\begin{array}{l}\text { ICD-10 CM: E08, E09, E10, E11, E13 } \\
\text { ICD-9-CM } 249 \text { to } 250\end{array}$ \\
\hline Chronic kidney disease & $\begin{array}{l}\text { ICD-10 CM: N18-1 to N18-9 } \\
2015 \text { ICD-9-CM 585.9 }\end{array}$ \\
\hline Chronic pulmonary disease & $\begin{array}{l}\text { ICD-10 CM: J44 } \\
2015 \text { ICD-9-CM } 491.21 \\
2015 \text { ICD-9-CM } 493.22 \\
\end{array}$ \\
\hline Malignancy & $\begin{array}{l}\text { ICD-10 CM: C38.0 } \\
2015 \text { ICD-9-CM } 164.1\end{array}$ \\
\hline
\end{tabular}




\begin{tabular}{|c|c|}
\hline Risk factor & Clinical code \\
\hline \multicolumn{2}{|c|}{ Cardiovascular comorbidities } \\
\hline Heart failure & \begin{tabular}{|l|} 
ICD-10 CM: I50 \\
2015 ICD-9-CM 428.1
\end{tabular} \\
\hline PAD & $\begin{array}{l}\text { ICD-10 CM: I73.9 } \\
\text { 2015 ICD-9-CM } 443.9\end{array}$ \\
\hline Cerebrovascular diseases & $\begin{array}{l}\text { ICD-10 CM: I67.9 } \\
2015 \text { ICD-9-CM } 437.9\end{array}$ \\
\hline \multicolumn{2}{|c|}{ Psychosocial characteristics } \\
\hline $\begin{array}{l}\text { Depression } \\
\text { Anxiety } \\
\text { Poor social support } \\
\text { Stress }\end{array}$ & $\begin{array}{l}\text { Psychological testing: 96101, 96102, } 96103 \\
\text { Psychotherapy: 90832-90853 } \\
\text { Health and behavior, assessment: 96150-96155 } \\
\text { ICD-10-CM Diagnosis Code F32.0, F33, F41 } \\
\text { 2015 ICD-9-CM } 296\end{array}$ \\
\hline Poverty & $\begin{array}{l}\text { ICD-10 CM: Z59.5 } \\
\text { 2015 ICD-9-CM V60.2 }\end{array}$ \\
\hline \multicolumn{2}{|r|}{ Other risk factors } \\
\hline $\begin{array}{l}\text { Psychosocial characteristics } \\
\text { Impaired psychological well being } \\
\text { Poor diet } \\
\text { Lack of exercise }\end{array}$ & $\begin{array}{l}\text { Psychological testing: 96101, 96102, } 96103 \\
\text { Psychotherapy: 90832-90853 } \\
\text { Health and behavior, assessment: 96150-96155 } \\
\text { ICD-10-CM Diagnosis Code F32.0, F33, F41 } \\
\text { 2015 ICD-9-CM } 296\end{array}$ \\
\hline Alcohol consumption & $\begin{array}{l}\text { Screening intervention of alcohol abuse: } 99408,99409 \\
\text { ICD-10-CM Diagnosis Code F10.29 } \\
2015 \text { ICD-9-CM } 291.9\end{array}$ \\
\hline Hypercholesterolemia & $\begin{array}{l}\text { ICD-10-CM I10 to I16 } 2015 \text { ICD-9-CM } 401 \text { to } 405 \\
\text { ICD-10-CM E78 } \\
2015 \text { ICD-9-CM } 272\end{array}$ \\
\hline Air pollution & $\begin{array}{l}\text { ICD-10 CM: Z77.110 } \\
\text { 2015 ICD-9-CM V15.89 }\end{array}$ \\
\hline
\end{tabular}

Source of the risk factors: Fihn et al. (2012).

\subsection{SIHD TREATMENT PROCEDURES}

Table 3 maps the SIHD procedures for a workup of chest pain, as found in Fihn et al. (2012), to the clinical codes (CPT, ICD-9, ICD-10, NDF). The table lists the noninvasive testing procedures; an invasive testing procedure, coronary angiography, which is used when noninvasive testing suggests high-risk coronary lesion(s); and the revascularization treatment procedures. 
Table 3. SIHD testing and treatment procedures

\begin{tabular}{|c|c|}
\hline Procedure & Clinical code \\
\hline \multicolumn{2}{|c|}{ Noninvasive testing procedure ${ }^{a, b}$} \\
\hline $\begin{array}{l}\text { Standard exercise electrocardiogram } \\
\text { (ECG) }\end{array}$ & $\begin{array}{l}\text { 93015-93018 } \\
\text { ICD10-CM R94.32 } \\
\text { ICD-9-CM 794.31 } \\
\text { ICD-10 CM I25.2 } \\
\text { ICD-9-CM 412 }\end{array}$ \\
\hline Echo with exercise & $\begin{array}{l}\text { ICD-10-CM Diagnosis Code R93.1 } \\
2015 \text { ICD-9-CM 793.2 }\end{array}$ \\
\hline $\begin{array}{l}\text { MPI (myocardial perfusion imaging) } \\
\text { with exercise }\end{array}$ & $\begin{array}{l}\text { 78451, 78452 } \\
\text { ICD-10-CM Diagnosis Code I51.5 } \\
\text { 2015 ICD-9-CM 429.1 } \\
\text { ICD-10-CM Diagnosis Code I21.9 } \\
\text { 2015 ICD-9-CM 410. }\end{array}$ \\
\hline Pharm stress echo & $\begin{array}{l}\text { ICD-10-CM Diagnosis Code R93.1 } \\
2015 \text { ICD-9-CM 793.2 }\end{array}$ \\
\hline Pharm stress MPI & $\begin{array}{l}\text { 78451, 78452 } \\
\text { ICD-10-CM Diagnosis Code I51.5 } \\
\text { 2015 ICD-9-CM 429.1 } \\
\text { ICD-10-CM Diagnosis Code I21.9 } \\
\text { 2015 ICD-9-CM 410. }\end{array}$ \\
\hline Pharm CMR & 75557, 75559, 75561, 75563, 93015-93018 \\
\hline CCTA & $75572,75573,75574,75571$ \\
\hline \multicolumn{2}{|c|}{ Invasive testing procedure $^{a}$} \\
\hline Coronary angiography & $\begin{array}{l}\text { 92975, 93454 } \\
\text { ICD-10-CM Diagnosis Code I25 } \\
\text { 2015 ICD-9-CM } 414 \\
\text { ICD-10-CM Diagnosis Code Z98.61 } \\
\text { 2015 ICD-9CM V45.82 }\end{array}$ \\
\hline \multicolumn{2}{|c|}{ Revascularization treatment procedure ${ }^{c}$} \\
\hline Coronary artery bypass graft (CABG) & $\begin{array}{l}\text { ICD-10-CM Diagnosis Code I25.79 } \\
\text { ICD-10-CM Diagnosis Code T82.213A } \\
\text { 2015 ICD-9-CM 996.03 }\end{array}$ \\
\hline $\begin{array}{l}\text { Percutaneous coronary intervention } \\
\text { (PCI)_-balloon angioplasty }\end{array}$ & $\begin{array}{l}\text { ICD-10-CM Diagnosis Code I21.A9 } \\
2015 \text { ICD-9-CM } 410\end{array}$ \\
\hline $\begin{array}{l}\text { PCI-Bare metal stent (BMS) } \\
\text { implantation }\end{array}$ & $\begin{array}{l}\text { ICD-10-CM Diagnosis Code I21.A9 } \\
2015 \text { ICD-9-CM } 410\end{array}$ \\
\hline $\begin{array}{l}\text { PCI_Drug eluting stent (DES) } \\
\text { implantation }\end{array}$ & $\begin{array}{l}\text { ICD-10-CM Diagnosis Code I21.A9 } \\
2015 \text { ICD-9-CM } 410\end{array}$ \\
\hline
\end{tabular}

${ }^{a}$ Source of the procedures: Figures 2 and 3 of Fihn et al. (2012).

${ }^{b}$ See Alo (2013) for a general overview of stress testing.

${ }^{c}$ Source of the procedures: Table 18 of Fihn et al. (2012). 


\subsection{DEFINITION OF SUCCESSFUL TREATMENT}

Almost half of the sharp decline in cardiovascular mortality seen over the past 40 years is attributable to interventions directed at changing risk factors. The initial approach for all patients should be centered on removing unhealthy behaviors such as smoking and effectively encouraging lifestyle changes (e.g., keeping a healthy weight, undertaking physical activity, implementing a healthy diet). In addition, for most patients, an evidence-based set of pharmacological interventions is indicated to reduce the risk of future events (Fihn et al. 2012).

The goals are to

- reduce premature cardiovascular death;

- prevent complications of SIHD that directly or indirectly impair patients' functional well-being, including nonfatal AMI and heart failure;

- maintain or restore a level of activity, functional capacity, and quality of life that is satisfactory to the patient;

- completely, or nearly completely, eliminate ischemic symptoms; and

- minimize costs of health care, in particular by eliminating avoidable adverse effects of tests and treatments, by preventing hospital admissions, and by eliminating unnecessary tests and treatments (Fihn et al. 2012).

The strategies are to

- educate patients about the etiology, clinical manifestations, treatment options, and prognosis of IHD to support active participation of patients in their treatment decisions;

- identify and treat conditions that contribute to, worsen, or complicate IHD;

- effectively modify risk factors for IHD by both pharmacological and nonpharmacological methods;

- use evidence-based pharmacological treatments to improve patients' health status and survival, with attention to avoiding drug interactions and side effects; and

- use revascularization by percutaneous catheter-based techniques or CABG when there is clear evidence of the potential to improve patients' health status and survival (Fihn et al. 2012).

Table 4 maps SIHD recommendations and outcomes to the clinical codes (CPT, ICD-9, ICD-10, NDF). 
Table 4. SIHD treatment strategies

\begin{tabular}{|c|c|c|}
\hline Risk factor & Recommendation & Clinical code \\
\hline \multicolumn{3}{|c|}{ Eliminating unhealthy behaviors } \\
\hline Smoking & Smoking cessation counseling (program). & $\begin{array}{l}99406 \\
99407 \\
\text { ICD-10-CM Diagnosis Code Z71.6 } \\
2015 \text { ICD-9-CM V65.42 }\end{array}$ \\
\hline Alcohol & $\begin{array}{l}\text { It might be reasonable for nonpregnant } \\
\text { women to have } 1 \text { drink ( } 4 \text { ounces of wine, } \\
12 \text { ounces of beer, or } 1 \text { ounce of spirits) a } \\
\text { day and for men to have } 1 \text { or } 2 \text { drinks a } \\
\text { day, unless alcohol is contraindicated } \\
\text { (such as in patients with a history of } \\
\text { alcohol abuse or dependence or with liver } \\
\text { disease). }\end{array}$ & $\begin{array}{l}\text { Screening intervention of alcohol abuse: } \\
\text { 99408, 99409 } \\
\text { ICD-10-CM Diagnosis Code F10.29 } \\
\text { 2015 ICD-9-CM } 291.9\end{array}$ \\
\hline \multicolumn{3}{|c|}{\begin{tabular}{|l|l} 
Lifestyle changes \\
\end{tabular}} \\
\hline $\begin{array}{l}\text { Maintaining a } \\
\text { healthy weight }\end{array}$ & $\begin{array}{l}\text { BMI between } 18.5 \text { and } 24.9 \mathrm{~kg} / \mathrm{m}^{2} \text { and a } \\
\text { waist circumference less than } 102 \mathrm{~cm}(40 \\
\text { inches) in men and less than } 88 \mathrm{~cm}(35 \\
\text { inches) in women (less for certain racial } \\
\text { groups). }\end{array}$ & $\begin{array}{l}\text { Psychotherapy: } 90832-90853 \\
\text { Health and behavior, assessment: } 96150- \\
96155 \\
\text { Health and behavior, assessment: } 96150- \\
96155 \\
\text { ICD-10-CM Diagnosis Code F32.0, F33, } \\
\text { F41 } \\
2015 \text { ICD-9-CM } 296\end{array}$ \\
\hline $\begin{array}{l}\text { Engaging in } \\
\text { physical activity }\end{array}$ & $\begin{array}{l}\text { For all patients, the clinician should } \\
\text { encourage } 30 \text { to } 60 \text { minutes of moderate- } \\
\text { intensity aerobic activity, such as brisk } \\
\text { walking, at least } 5 \text { days and preferably } 7 \\
\text { days per week, supplemented by an } \\
\text { increase in daily lifestyle activities (e.g., } \\
\text { walking breaks at work, gardening, } \\
\text { household work) to improve } \\
\text { cardiorespiratory fitness and move patients } \\
\text { out of the least-fit, least-active, high-risk } \\
\text { cohort (bottom } 20 \% \text { ) (602-604). (Level of } \\
\text { Evidence: B). } \\
\text { For all patients, risk assessment with a } \\
\text { physical activity history and/or an exercise } \\
\text { test is recommended to guide prognosis } \\
\text { and prescription (605-608). (Level of } \\
\text { Evidence: B). } \\
\text { Medically supervised programs (cardiac } \\
\text { rehabilitation) and physician-directed, } \\
\text { home-based programs are recommended } \\
\text { for at-risk patients at first diagnosis } \\
\text { (602,609,610). (Level of Evidence: A). }\end{array}$ & $\begin{array}{l}\text { Health and behavior, assessment: } 96150- \\
96155 \text {. } \\
\text { Athletic training: } 97169-97172 \\
\text { Health and behavior, assessment: } 96150- \\
96155 \\
\text { ICD-10-CM Diagnosis Code F32.0, F33, } \\
\text { F41 } \\
2015 \text { ICD-9-CM } 296\end{array}$ \\
\hline $\begin{array}{l}\text { Adopting a } \\
\text { healthy diet }\end{array}$ & $\begin{array}{l}\text { Dietary therapy for all patients should } \\
\text { include reduced intake of saturated fats (to } \\
<7 \% \text { of total calories), trans fatty acids (to } \\
<1 \% \text { of total calories), and cholesterol (to } \\
<200 \mathrm{mg} / \mathrm{d})(18,497-500) \text {. (Level of } \\
\text { Evidence: B). }\end{array}$ & $\begin{array}{l}\text { Health and behavior, assessment: } 96150- \\
96155 . \\
\text { ICD-10-CM Diagnosis Code Z71.3 } \\
2015 \text { ICD-9-CM V65.3 }\end{array}$ \\
\hline
\end{tabular}




\begin{tabular}{|c|c|c|}
\hline Risk factor & Recommendation & Clinical code \\
\hline \multicolumn{3}{|c|}{ Pharmacological interventions } \\
\hline $\begin{array}{l}\text { Include anti- } \\
\text { platelet agents }\end{array}$ & $\begin{array}{l}\text { Treatment with aspirin, } 75 \text { to } 162 \mathrm{mg} \text { daily, } \\
\text { should be continued indefinitely in the } \\
\text { absence of contraindications in patients } \\
\text { with SIHD (716, 717). (Level of Evidence: } \\
\text { A). } \\
\text { Treatment with clopidogrel is reasonable } \\
\text { when aspirin is contraindicated in patients } \\
\text { with SIHD (718). }\end{array}$ & $\begin{array}{l}\text { ICD-10-CM Diagnosis Code Z79.02 } \\
2015 \text { ICD-9-CM V58.63 }\end{array}$ \\
\hline Statins & & $\begin{array}{l}\text { One example: NDC } 43598-318 \text { (amlodipine } \\
\text { besylate and atorvastatin calcium) }{ }^{a}\end{array}$ \\
\hline Beta blockers & $\begin{array}{l}\text { Beta-blocker therapy should be started and } \\
\text { continued for } 3 \text { years in all patients with } \\
\text { normal liver (LV) function after } \\
\text { myocardial infarction (MI) or ACS (757- } \\
\text { 759). (Level of Evidence: B). } \\
\text { Beta-blocker therapy should be used in all } \\
\text { patients with LV systolic dysfunction (EF } \\
\text { <40\%) with heart failure or prior MI, } \\
\text { unless contraindicated. (Use should be } \\
\text { limited to carvedilol, metoprolol succinate, } \\
\text { or bisoprolol, which have been shown to } \\
\text { reduce risk of death.) }\end{array}$ & $\begin{array}{l}\text { One example: NDC 0378-1200 (acebutolol } \\
\text { hydrochloride) }{ }^{a}\end{array}$ \\
\hline $\begin{array}{l}\text { Other agents to } \\
\text { control } \\
\text { hypertension }\end{array}$ & $\begin{array}{l}\text { Angiotensin-converting enzyme (ACE) } \\
\text { inhibitors should be prescribed in all } \\
\text { patients with SIHD who also have } \\
\text { hypertension, diabetes mellitus, Left } \\
\text { ventricle ejection fraction (LVEF) } 40 \% \text { or } \\
\text { less, or chronic kidney disease (CKD), } \\
\text { unless contraindicated (295-298, 301). } \\
\text { (Level of Evidence: A). } \\
\text { Angiotensin II receptor blockers (ARBs) are } \\
\text { recommended for patients with SIHD who } \\
\text { have hypertension, diabetes mellitus, LV } \\
\text { systolic dysfunction, or CKD and have } \\
\text { indications for, but are intolerant of, ACE } \\
\text { inhibitors. }\end{array}$ & $\begin{array}{l}\text { One example: NDC 68071-1825 } \\
\text { (amlodipine and benazepril } \\
\text { hydrochloride) })^{a}\end{array}$ \\
\hline
\end{tabular}

${ }^{a}$ From the National Drug Code (NDC) Directory, https://www.accessdata.fda.gov/scripts/cder/ndc/index.cfm Source of risk factors and recommendations: Fihn et al. (2012).

\subsection{SIHD CLINICAL PATHWAYS}

We studied the pathways provided in Figures 2-6 of the 2012 ACCF guideline, but we found the pathways difficult to use for our purposes. To aid our understanding, we redrew these figures (shown in Appendix B as Figures B-2 through B-6) using software engineering notation in the Unified Modeling Language (UML) and included pathway map considerations and a legend. To simplify our repeated reference to each item in the figures, we added a unique identification number to each box in the flow charts.

In addition, we studied Business Processing Modeling Notation (BPMN) and considered the possibility of presenting the flow charts in BPMN. However, in this particular case, we realized that BPMN is not 
different from the technique already used in UML, as the types of conditions or gateways can be presented as they are. Consequently, we retained the UML-modified figures.

\section{GAME-THEORETIC MODELING APPROACH}

This section describes the general game-theoretic approach for modeling clinical interventions.

\subsection{MOTIVATION FOR MODELING APPROACH}

Prior work in the statistical analysis of the effectiveness of clinical pathways (e.g., Romanova 2015) took observational data, such as the CDW, and directly estimated the effectiveness of a specific clinical pathway. However, as Figure 1 illustrates, we take a different approach: modeling the effects of clinical interventions on a patient as a formal mathematical model, which is a single-player game with the physician as the player, making decisions about which diagnostics and treatments to utilize.

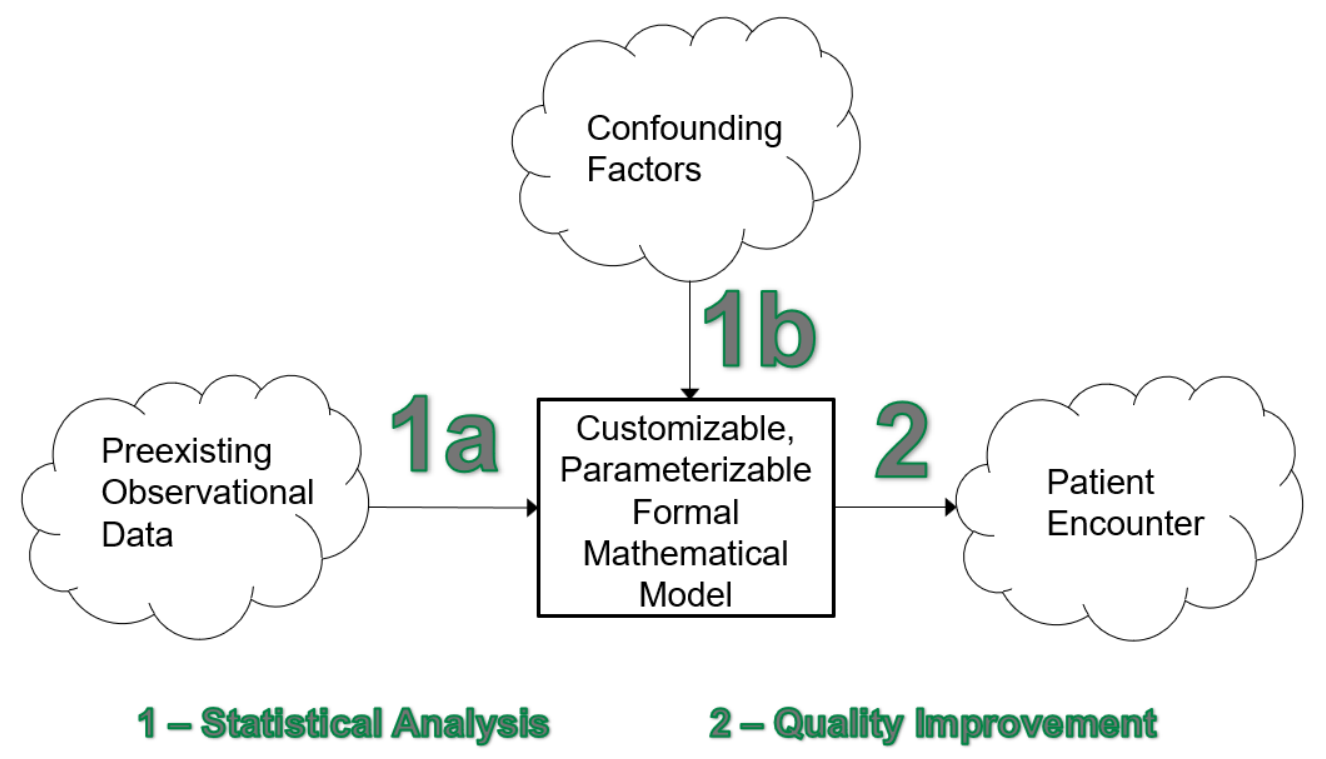

Figure 1. Game theory as a formal model for patient response to clinical interventions.

To illustrate the difference with our new approach, consider Figure B-2 in Appendix B, which represents a clinical pathway from the 2012 ACCF guideline for SIHD. It shows the recommended way to select which cardiac stress test to use in the workup of a given patient. Alternatively, consider Table 5, which is a screen shot of the top half of Table 11 from the 2012 ACCF guideline for SIHD. This table shows not only the recommended cardiac stress test to use but also the result of using a non-recommended cardiac stress test. It is this fuller information that the formal mathematical model in the box in Figure 1 seeks to capture. 
Table 5. Stress testing recommendations from the 2012 ACCF guideline

Table 11. Stress Testing and Advanced Imaging for Initial Diagnosis in Patients With Suspected SIH Who Require Noninvasive Testing

\begin{tabular}{|c|c|c|c|c|c|c|c|c|}
\hline \multirow[b]{2}{*}{ Test } & \multicolumn{2}{|c|}{$\begin{array}{l}\text { Exercise } \\
\text { Status }\end{array}$} & \multicolumn{2}{|c|}{$\begin{array}{c}\text { ECG } \\
\text { Interpretable }\end{array}$} & \multicolumn{3}{|c|}{ Pretest Probability of IHD } & \multirow[b]{2}{*}{ COR } \\
\hline & Able & Unable & Yes & No & Low & Intermediate & High & \\
\hline \multicolumn{9}{|l|}{ Patients able to exercise* } \\
\hline Exercise ECG & $\mathrm{x}$ & & $\mathrm{x}$ & & & $\mathrm{X}$ & & 1 \\
\hline $\begin{array}{l}\text { Exercise with nuclear MPI } \\
\text { or Echo }\end{array}$ & $\mathrm{x}$ & & & $\mathbf{x}$ & & $\mathrm{x}$ & $\mathrm{x}$ & 1 \\
\hline Exercise ECG & $\mathrm{x}$ & & $\mathrm{x}$ & & $\mathrm{x}$ & & & Ila \\
\hline $\begin{array}{l}\text { Exercise with nuclear MPI } \\
\text { or Echo }\end{array}$ & $\mathrm{x}$ & & $\mathrm{x}$ & & & $\mathrm{X}$ & $\mathrm{X}$ & Ila \\
\hline Pharmacological stress CMR & $\mathrm{x}$ & & & $\mathrm{x}$ & & $\mathrm{X}$ & $\mathbf{X}$ & Ila \\
\hline CCTA & $\mathrm{x}$ & & \multicolumn{2}{|c|}{ Any } & & $\mathrm{X}$ & & Ilb \\
\hline Exercise Echo & $\mathrm{x}$ & & $\mathrm{x}$ & & & $\mathrm{X}$ & & Ilb \\
\hline $\begin{array}{l}\text { Pharmacological stress with } \\
\text { nuclear MPI, Echo, or CMR }\end{array}$ & $\mathrm{x}$ & & $\mathrm{x}$ & & \multicolumn{3}{|c|}{ Any } & III: No Benefit \\
\hline $\begin{array}{l}\text { Exercise stress with nuclear } \\
\text { MPI }\end{array}$ & $\mathrm{x}$ & & $\mathrm{x}$ & & $\mathrm{x}$ & & & III: No Benefit \\
\hline \multicolumn{9}{|l|}{ Patients unable to exercise } \\
\hline $\begin{array}{l}\text { Pharmacological stress with } \\
\text { nuclear MPI or Echo }\end{array}$ & & $\mathrm{x}$ & \multicolumn{2}{|c|}{ Any } & & $\mathrm{x}$ & $\mathrm{x}$ & 1 \\
\hline Pharmacological stress Echo & & $\mathrm{x}$ & \multicolumn{2}{|c|}{ Any } & $\mathrm{x}$ & & & Ila \\
\hline CCTA & & $\mathrm{x}$ & \multicolumn{2}{|c|}{ Any } & $\mathrm{x}$ & $\mathrm{X}$ & & Ila \\
\hline Pharmacological stress CMR & & $x$ & \multicolumn{2}{|c|}{ Any } & & $\mathrm{x}$ & $\mathrm{x}$ & Ila \\
\hline Exercise ECG & & $\mathrm{x}$ & & $x$ & & Any & & III: No Benefit \\
\hline
\end{tabular}

Source: Fihn et al. (2012).

\subsection{USING GAME THEORY AS A MATHEMATICAL MODEL}

To model clinical pathways, we use an approach based in game theory. Game theory is the study of mathematical models represented by players (agents) making decisions based on possible options to obtain certain outcomes. In the case at hand, our mathematical model also could be thought of as an instance of decision theory. We apply a particular type of game theory named Bayesian game theory (Figure 2) (Manea 2016). In Bayesian game theory, players lack several pieces of information on the available decisions; however, players can make assumptions based on the probabilities of possible decisions to obtain the desired outcomes when information is hidden or unknown. 


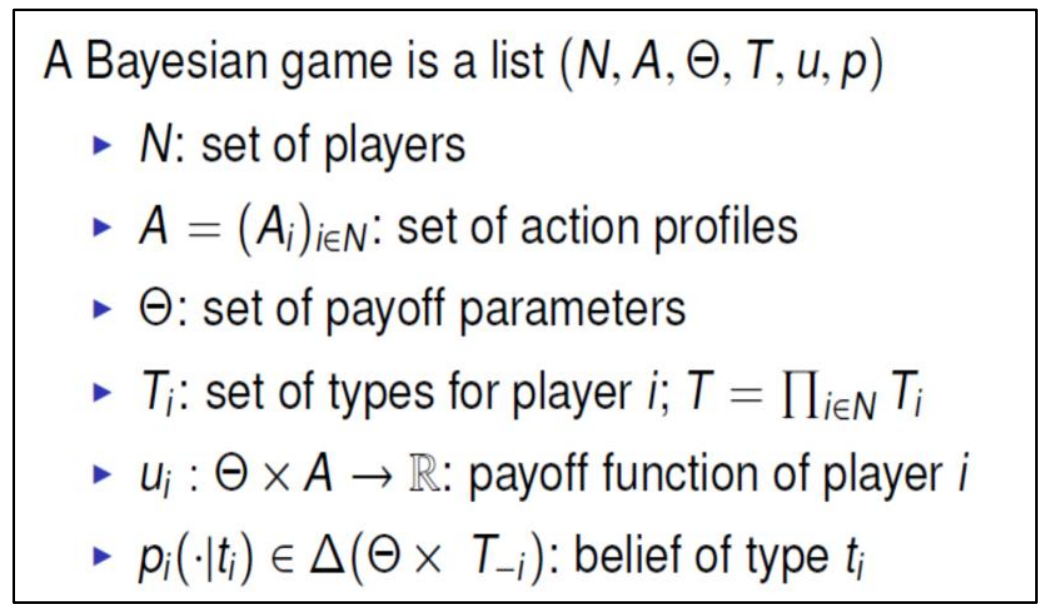

Figure 2. Definition of a Bayesian game from Manea (2016).

In its most simple form, Bayesian game theory has the following elements:

1. a set of players, $N$

2. a set of actions or moves of each player, $A_{i}$

3. a set of states that can influence the actions, $E$

4. a set of outcomes of each move, $O$

5. the probability distribution over the set of states in item (2) above, $p_{i}$

Table 6 maps the elements above to the clinical pathway for SIHD, our use case in this document; however, the theory could be applied to other clinical pathways as use cases.

Table 6. Mapping from Bayesian game theory to the clinical pathway for SIHD

\begin{tabular}{|l|l|}
\hline \multicolumn{1}{|c|}{ Bayesian game theory element } & \multicolumn{1}{c|}{ Mapping to clinical pathway } \\
\hline Set of players, $N$ & Physicians \\
\hline Actions or rules of how to play the game, $A_{i}$ & Include every step or clinical action in the clinical pathway \\
\hline States or board, $E_{i}$ & Physical condition or risk factors \\
\hline Outcomes, $O_{i}$ & Effect of the move on the patient's health condition \\
\hline Probability distribution, $p_{i}$ & Likelihood of the different outcomes \\
\hline
\end{tabular}

\subsection{STATISTICAL ANALYSIS OF GAME THEORY PARAMETERS}

The statistical analysis of game theory parameters follows the steps below.

1. Identify the SIHD use case. Select a particular doctor-patient interaction to model.

2. Identify alternative moves. Try to identify a decision point in the doctor-patient interaction (encounters or visits) at which the doctor can choose options based on the clinical pathway.

3. Identify the move outcomes. Use Section 3.4, Definition of Successful Treatment, and determine whether or not the test helped the patient.

4. Identify confounding factors. Use the definitions given Table 2-Table 4 in and Figure 1, item 1b. Note that use of the figure requires medical knowledge. 
5. Select an analysis type, either parametric or nonparametric. Parametric analysis, the more advanced type, requires assumptions on how the different confounding factors affect the outcomes.

Nonparametric analysis requires minimal assumptions and is typically used when data is too scarce to provide meaningful results.

6. Perform the analysis by applying the game theory model. The result of the analysis is a formula for the outcome of probabilities.

7. Apply the information obtained in steps 1-6 to more recent patient data, as described in Section 4.4.

\subsection{QUALITY IMPROVEMENT USING GAME THEORY MODELS}

The game theory modeling approach to quality improvement has the following steps. Due to lack of medically-significant outcome information in the CDW data, these steps have not yet been applied using actual patient data. However, once medically-significant outcome data can be obtained, the ability to compare diagnostic and treatment methods using game theory parameters specific to a smaller subcohort should result in quality improvement via better selection of those diagnostic and treatment methods.

1. Select a current (or past) patient encounter on which to apply game theory analysis.

2. Identify relevant use cases for which game theory modeling and statistical analysis have been performed.

3. Obtain a prior distribution for the patient population on which the Bayesian analysis will be performed.

4. Enter the current patient characteristics into the game theory model to determine the outcome probabilities for each alternative diagnostic and/or treatment path forward.

5. Work with the patient to combine the various outcome aspects into an overall objective function value.

6. Select the best move based on the overall objective function value.

\subsection{GUIDELINE OPTIMIZATION}

Each use case in the game theory analysis provides insight to a particular treatment outcome. Once enough treatment outcomes have been modeled, they can be used to optimize the application of clinical guidelines to different patient subpopulations.

Given some radiological/investigation choices (seven workup choices for SIHD, as shown in Figure 2 of the 2012 guideline), we need to determine if some specific subcohorts would benefit from slight modifications or refinement of the general population guideline. Slight modifications or refinement would involve adding additional branches/conditional nodes to create a more efficient path to either workup/investigation steps or treatment alternatives. This is similar to the original task of using data/evidence associated with published outcomes to create the original population-based guideline, but we want to take that further and use automated methods and automated analytics on data to refine (i.e., create) a guideline optimized for an arbitrary subcohort in real time (based on the immense dataset available from the VA clinical population). Three examples of refinements for optimization are given here. 
1. Age-specific cohort guideline optimization: In the guideline diagrams in Appendix B, an elderly subcohort with high-risk prior probability of SIHD would be best served by directly going to cardiac MRI rather than following the course of the general population, who would first go through EKG, stress test, and so on before needing a cardiac MRI. This illustrates how the guideline could be refined to be optimized for a specific subcohort.

2. Cross-medical condition guideline issue: If a patient has a heart valve problem, this might be an exception comorbidity, which compromises the patient's ability to undergo a physical stress test; thus, going directly to cardiac MRI would be better approach.

3. Rare comorbidities, undiscovered or unexamined confounders, or effect modifiers: A patient with Parkinson's disease may need an optimized workup, but we have not had a large enough dataset to see if the variable of Parkinsonism affects empirical outcomes for optimal testing (even if causal understanding of this is still unknown).

\subsection{AGENT MAPPING}

Agent 1 is the general population/original guideline. This structured set includes all the trade-offs and all the encapsulated players, incentives, outcome perspectives, elements, and total social-utility objective functions as givens. The structure of the game includes parameters to represent these incorporated tradeoffs from the general population perspective.

Agent 2 is the specific new subcohort/refined guideline. This subcohort is characterized by the specific parameters that are different for this cohort compared with those of the Agent 1 cohort. The subcohort may have only one parameter that is different, or multiple parameters. But even if only one parameter is different, a tension exists between how optimal the general guideline would be versus how optimal a more case-specific or cohort-specific refined guideline would be for this subcohort. We can show this by using the empirical dataset.

Our intuition tells us that this is like an $n$-body problem in physics reduced to a two-body problem by just considering perturbations on the $n$-body problem; just one new perturbation would be the second body, and all the previous equilibrium of the original-body solution would be the first body.

Intuitively, we believe strategic behavior or game theory is relevant to the above task because given a specific subcohort, the cost or utility or other objective functions/equilibrium conditions that are true for the general population guidelines may not, by use of game theory, hold as optimally for the subcohort. Thus, a new refined guideline would allow the equilibrium condition for a game to be reestablished (i.e., cost versus benefit, extra testing versus more efficient workup, etc.).

The payoff matrix in Figure 3, created from Figures B-2 and B-3 on stress testing from the 2012 ACCF guideline, is the expected result of applying game theory analysis to the selection of stress test. 


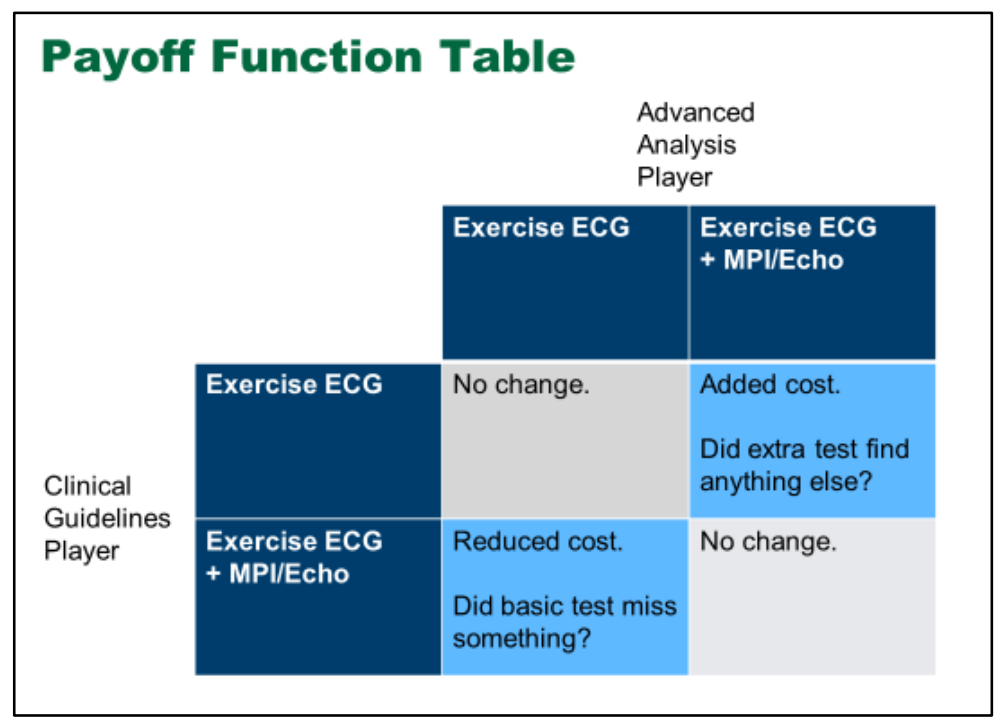

Figure 3. Payoff function table.

By identifying subpopulations with higher-than-expected risk of SIHD, the additional expense of an advanced stress test modality can be justified. By identifying subpopulations with lower-than-expected risk of SIHD, the reduced diagnostic ability of a basic stress test can be justified.

To proceed along this line of analysis, the following steps need to be performed:

1. State the subcohort examples more directly, and review with subject matter experts.

2. Determine the important parameters for modeling the general guideline to use as a substrate for the game.

3. Set up a $2 \times 2$ basic game for general cohort versus special subcohort (or similar game) that would be an example of a one-parameter change (e.g., age change or probability of IHD).

4. Show how game equilibrium (i.e., guideline) changes the general guideline to something that is refined by one move.

To execute these steps to complete the game theory formulation and implementation, we need to develop the full model, including parameters for the payoff and player strategies, using empirical data extraction from the VA CDW dataset. Model development is discussed in the next section.

\section{DEVELOPMENT OF SIHD MODELS}

This section discusses our work in creating a game theory model for SIHD. Sections 5.1 and 5.2 review the relevant ICD-10 and ICD-9 codes for SIHD. Section 5.3 discusses the cohort we used for statistical analysis. Section 5.4 discusses the specific use case of stress testing for SIHD diagnosis. Section 5.5 reviews the CDW data for the selected cohort and gives initial analysis results. Finally, Section 5.6 breaks down the cohort data by identifying two confounding factors, the presence of diabetes and smoking. 


\subsection{ICD-10 CLINICAL MODIFICATION CODES}

The WHO's 2018 release of ICD-CM-10 (CDC 2018) was consulted to determine the ICD-10-CM codes to use in this study. The common cardiovascular disease codes are shown in Appendix A. The following codes are taken from ICD10 data (2018).

ICD-10 CM Codes > I00-I99 Diseases of the circulatory system > I20-I25 Ischemic heart diseases.

Codes:

- I20, angina pectoris

- I21, acute myocardial infarction

- I22, subsequent ST elevation myocardial infarction (STEMI) and non-ST elevation myocardial infarction (NSTEMI)

- I23, certain current complications following STEMI and NSTEMI (within the 28-day period)

- I24, other acute ischemic heart diseases

- $\mathrm{I} 25$, chronic ischemic heart disease

The following are possible precursors to IHD:

- ICD-10 I10 to I16 (ICD-9 401 to 405), hypertensive diseases

- ICD-10 E66 (ICD-9 270.0), overweight and obesity

- ICD-10 E78 (ICD-9 272), disorders of lipoprotein metabolism and other lipidemias

- ICD-10 E88.81 (ICD-9 277.7), metabolic syndrome

- ICD-10 Z82.49 (ICD-9 V17.49), code for family history

\subsection{ICD-9 CODES}

The following ICD-9 codes were used in this study:

2012 ICD-9-CM Diagnosis Codes > Diseases Of The Circulatory System 390-459 > Ischemic Heart Disease 410-414

- ICD-9 410 to 414 (ICD-10 I20 to I25), ischemic heart disease

- 410, acute myocardial infarction

- 411, other acute and subacute forms of ischemic heart disease

- 412, old myocardial infarction

- 413 , angina pectoris

- 414 , other forms of chronic ischemic heart disease

\subsection{HIT-AA SIHD TARGET COHORTS FOR DATA ANALYSIS}

During this study, the team created a dataset from CDW with the following criteria.

\section{Cohort Analytics Target}

(Fe)male patients between 50 and 60 years of age who have diabetes mellitus controlled with pharmacological therapy, have a history of MI [have typical angina], and have had a cardiac stress test. 
(Failing a stress test indicates a likelihood of severe coronary stenosis of $>60 \%$ ). In addition, we focused on those patients who are also smokers.

\section{Query Protocol}

Step 1: Deidentified (fe)male patients, between 50 and 60 years of age

Step 2: Cohort in step 1 who also satisfy:

a. Diabetes mellitus type II

1. All the ICD-9-CM (or ICD-10) for Diabetes Mellitus Type II (DMII)

b. On pharma therapy

1. All pharma drug classes with active prescription for DMII therapy (Look for these in references, with VA drug class codes to search for.)

c. Well-controlled with pharma therapy

1. HA1C $\leq 7 \%$ in the last 12 months

Step 3: Have history of previous MI

a. AMI codes in past medical history diagnosis list or problem list. (See references to identify these.)

Step 4: Have had a cardiac stress test

a. In the past 12 months, have had a cardiac stress test

\subsection{STRESS TEST SELECTION FOR SIHD DIAGNOSIS}

In this case, we identified CDW users who have had encounters with the CPT codes related to the procedures described in Figure 2 of the 2012 ACCF guideline. Those related to the boxes numbered 263, 264, 281, 285, 286, 287 and 288 appear in Figure B-2 of Appendix B. Users with CPT codes related to the procedures in Figure 2 are shown in Table 7.

Table 7. Stress tests

\begin{tabular}{|l|l|l|}
\hline \multirow{4}{*}{ Exercise } & \multicolumn{1}{|c|}{ Test type } & \multicolumn{1}{c|}{ Clinical pathway item number } \\
\cline { 2 - 3 } & ECG Only & 285,286 \\
\cline { 2 - 3 } & ECG + MPI & $281 \mathrm{a}, 287 \mathrm{a}$ \\
\cline { 2 - 3 } Pharmacology & ECG + ECHO & $281 \mathrm{~b}, 287 \mathrm{~b}$ \\
\cline { 2 - 3 } & ECG + MPI & $263 \mathrm{a}$ \\
\cline { 2 - 3 } & ECG + ECHO & $263 \mathrm{~b}, 264$ \\
\cline { 2 - 3 } & Pharm CMR & $265 \mathrm{a}, 287 \mathrm{c}$ \\
\hline \multirow{2}{*}{ Other } & CCTA & $265 \mathrm{~b}, 288$ \\
\hline
\end{tabular}

Initially, we considered including the CPT codes for cardiovascular magnetic resonance (CMR) imaging and computed coronary tomography angiography (CCTA) following the diagnosis SIHD clinical pathway (see Figure 2 of the 2012 ACCF guideline). However, we found that these tests did not apply directly to our study because they are rarely used and did not apply directly to the dataset we selected; consequently, we decided to postpone the study of CMR and CCTA. 


\subsection{OVERALL STRESS TEST DATA}

In our current set of CDW data, the results of cardiac stress tests (e.g., pass/fail, Duke Treadmill Score, or the more extensive VA stress test score) are not available. Thus, for an outcome to use for our analysis, we chose to divide the administered stress tests into two categories: good and bad, based on whether the drug aminophylline was needed (or at least used) to reverse the effects of the stress.

We initiated our analysis by collecting the data, shown in Table 8 , for the patients who had good test results or bad test results depending on the different type of test. Note that for this dataset, when the tests were applied with the use of pharmacological agents, the number of patients with bad results increased considerably. More importantly, note that the CDW data (in particular, the CPT codes corresponding to an outpatient visit) indicated that more than 2,000 tests were performed with a pharmacological stress agent but without an additional modality, such as MPI or echocardiogram (ECHO), beyond the basic 12lead electrocardiogram (ECG). According to subject matter experts, this is not an accepted medical procedure, so we ignored the data for such situations in the detailed statistical analysis shown in the next section.

Table 8. SIHD diagnosis dataset (CDW)

\begin{tabular}{|l|l|c|c|}
\hline \multirow{3}{*}{ Stress type } & Test type & $\begin{array}{c}\text { \# of patients with } \\
\text { good results }\end{array}$ & $\begin{array}{c}\text { \# of patients with } \\
\text { bad results }\end{array}$ \\
\hline \multirow{3}{*}{ Exercise } & ECG Only & 17,896 & 4 \\
\cline { 2 - 4 } & ECG + MPI & 5,315 & 1 \\
\cline { 2 - 4 } & ECG + ECHO & 571 & 0 \\
\hline \multirow{3}{*}{ Pharmacology } & ECG Only* & 1,912 & 151 \\
\cline { 2 - 4 } & ECG + MPI & 4,288 & 239 \\
\cline { 2 - 4 } & ECG + ECHO & 192 & 0 \\
\hline
\end{tabular}

*More than 2,000 tests were performed with a pharmacological stress agent but without an additional modality, such as MPI or ECHO, beyond the basic 12-lead electrocardiogram (ECG).

\subsection{STRESS TEST DATA BY CONFOUNDING FACTOR}

Breaking down the stress test data by confounding factor yields the analysis shown in Table 9. A sample of the raw data is contained in Appendix C.

The confidence interval analysis was performed using the Python "statsmodels" package. The standard significance level of $p=0.05$, or $5 \%$, was used. To understand what this means, we look at the diabetic smokers' Pharmacology ECG + MPI row of Table 9. The confidence interval found there was 237.0780.5 per 10,000 patients. The statistical statement corresponding to that confidence interval is the following: (1) if the actual probability of a bad result is less than 237.0 per 10,000 patients, then there is a less than $2.5 \%$ (half of $p$ ) probability of seeing the raw data of 12 bad results vs. 252 good results; and (2) if the actual probability of a bad result is greater than 780.5 per 10,000 patients, then there is also a less than $2.5 \%$ (half of p) probability of seeing the raw data of 12 bad results vs. 252 good results. 
Table 9. SIHD diagnosis dataset arranged by confounding factor

\begin{tabular}{|c|c|c|c|c|}
\hline Stress type & Test type & $\begin{array}{l}\text { \# of patients with } \\
\text { good results }\end{array}$ & $\begin{array}{c}\text { \# of patients with } \\
\text { bad results }\end{array}$ & $\begin{array}{l}\text { Confidence interval of bad } \\
\text { results per } 10,000 \text { patients } \\
\text { (at } p=0.05)\end{array}$ \\
\hline \multicolumn{5}{|c|}{ Diabetic smokers } \\
\hline \multirow[t]{3}{*}{ Exercise } & ECG Only & 783 & 0 & $0-47.0$ \\
\hline & $\mathrm{ECG}+\mathrm{MPI}$ & 228 & 0 & $0-160.5$ \\
\hline & $\mathrm{ECG}+\mathrm{ECHO}$ & 17 & 0 & $0-1950.6$ \\
\hline \multirow[t]{2}{*}{ Pharmacology } & ECG + MPI & 252 & 12 & $237.0-780.5$ \\
\hline & $\mathrm{ECG}+\mathrm{ECHO}$ & 11 & 0 & $0-2849.1$ \\
\hline \multicolumn{5}{|c|}{ Diabetic nonsmokers } \\
\hline \multirow[t]{3}{*}{ Exercise } & ECG Only & 2,144 & 1 & $0.1-25.9$ \\
\hline & $\mathrm{ECG}+\mathrm{MPI}$ & 510 & 0 & $0-72.1$ \\
\hline & $\mathrm{ECG}+\mathrm{ECHO}$ & 39 & 0 & $0-902.5$ \\
\hline \multirow[t]{2}{*}{ Pharmacology } & ECG + MPI & 472 & 45 & $642.0-1147.3$ \\
\hline & ECG + ECHO & 16 & 0 & $0-2059.1$ \\
\hline \multicolumn{5}{|c|}{ Nondiabetic smokers } \\
\hline \multirow[t]{3}{*}{ Exercise } & ECG Only & 1,757 & 2 & $1.4-41.0$ \\
\hline & ECG + MPI & 445 & 0 & $0-82.6$ \\
\hline & $\mathrm{ECG}+\mathrm{ECHO}$ & 41 & 0 & $0-860.4$ \\
\hline \multirow[t]{2}{*}{ Pharmacology } & ECG + MPI & 400 & 28 & $439.1-931.7$ \\
\hline & $\mathrm{ECG}+\mathrm{ECHO}$ & 13 & 0 & $0-2470.5$ \\
\hline \multicolumn{5}{|c|}{ Nondiabetic nonsmokers } \\
\hline \multirow[t]{3}{*}{ Exercise } & ECG Only & 13,212 & 1 & $0.0-4.2$ \\
\hline & $\mathrm{ECG}+\mathrm{MPI}$ & 4,132 & 1 & $0.1-13.5$ \\
\hline & $\mathrm{ECG}+\mathrm{ECHO}$ & 474 & 0 & $0-77.5$ \\
\hline \multirow[t]{2}{*}{ Pharmacology } & ECG + MPI & 3,164 & 154 & $395.1-541.3$ \\
\hline & ECG + ECHO & 152 & 0 & $0-239.8$ \\
\hline
\end{tabular}

\subsection{PRELIMINARY RESULTS AND LESSONS LEARNED}

Based on the work performed to date, we have strong confidence that mathematical analysis can be performed on existing CDW data to yield statistically significant confidence intervals. For the appropriate selection of outcomes, this analysis can be directly relevant to the selection of clinical treatments. Once a complete set of outcomes has been analyzed, the results can be used to assess the efficacy of a clinical pathway.

The following lessons were learned during the course of our work:

1. Erroneous CDW data can still point to relevant medical information. For example, having CPT codes for both a colonoscopy and a cardiac stress test on the same day may mean that both procedures actually occurred, but on different days. Similarly, having codes for pharmacological stress agents 
without codes for advanced test modalities (MPI or ECHO) may mean that the coder neglected to include the appropriate CPT code for those advanced test modalities.

2. The hardest part of analyzing CDW data using game theory is determining the outcomes-for example, the results of the diagnostic tests. In some cases, the results seem to only exist in the natural language text notes, if at all.

3. Information from basic clinical examination of a patient may be unavailable. For example, heart sounds provide key diagnostic information to the physician, but it is unclear to what extent abnormal heart sounds are regularly recorded as ICD-9 or ICD-10 codes.

\subsection{FUTURE WORK RECOMMENDATION}

The results of the work performed to date provide several ideas for possible future work. These recommendations can be grouped into the following general categories:

1. Continuation of the present game theory approach

Effort is currently being made to obtain access to additional sources of outcome data in the CDW, including natural language notes, which contain more relevant outcome information. Also, additional databases, such as the cardiac CART database, can provide information to as to the diagnostic effectiveness of the various types of cardiac stress tests.

\section{Correction of inaccurate/incomplete CDW data}

Based on conversations with subject matter experts, it appears that inaccuracies and/or incomplete data in the CDW are still sufficient, in combination with knowledge of standard medical procedures, to provide information about the likely clinical treatments performed. In particular, it seems possible and desirable to develop a method to automatically correct problematic CDW data based on general correction patterns provided by subject matter experts.

Additionally, it should be possible to develop a method to automatically search the CDW data for anomalies as compared with a given game theory analysis.

3. Combination of game theory results with ORNL's machine learning approaches (See HIT-AA: Research Tasks FY 2017-2018 Report.)

The game theory approach requires subject matter expert information to identify the relevant confounding factors for a clinical treatment. However, once the outcomes have been extracted from the CDW data, it should be possible to use a clustering approach to automatically identify, without prior subject matter expert information, the common characteristics of patients who have similar outcomes.

The data correction effort from item 2 should provide much cleaner data for identifying existing clinical pathways. Currently, incorrect CPT codes are finding their way into the clinical pathways identified using machine learning. 


\section{ACKNOWLEDGEMENTS}

The authors are most grateful to the staff of the US Department of Veterans Affairs for their support of Oak Ridge National Laboratory as part of the FY 17-18 ORNL VICTOR Part A, Part B: Health Information Technology-Advanced Analytics project. Special thanks are extended to Dr. Jonathan Nebeker, Dr. Tamara Box, and Dr. Merry Ward and their teams of subject matter experts at the VA for their technical expertise and helpful discussions they provided in support of this effort.

\section{REFERENCES}

CDC. (2015). Health equity. Retrieved from https://www.cdc.gov/women/lcod/2015/raceethnicity/index.htm

CDC. (2018). International classification of diseases, tenth revision, clinical modification (ICD-10-CM). Retrieved from https://www.cdc.gov/nchs/icd/icd10cm.htm

Fihn, S. D., Gardin, J. M., Abrams, J., Berra, K., Blankenship, J. C., Douglas, P. S., \& Kligfield, P. D. (2012). "2012 ACCF/AHA/ACP/AATS/PCNA/SCAI/STS guideline for the diagnosis and management of patients with stable ischemic heart disease: A report of the American College of Cardiology Foundation/American Heart Association Task Force on Practice Guidelines, and the American College of Physicians, American Association for Thoracic Surgery, Preventive Cardiovascular Nurses Association, Society for Cardiovascular Angiography and Interventions, and Society of Thoracic Surgeons." Journal of the American College of Cardiology, 60(24), e44e164.

ICD10data. (2018). ICD10data.com. http://www.icd10data.com/

Manea, Mihai. (2016). Game Theory. Course 14.126. Spring 2016. Massachusetts Institute of Technology: MITOpenCourseWare. Retrieved from https://ocw.mit.edu/courses/economics/14126-game-theory-spring-2016/

OnlineMedEd. 2016. Cardiology: coronary artery disease. Retrieved from Youtube video: https://www.youtube.com/watch?v=pzM-uOOYccQ

Romanova, A. V. (2015). Evaluating the effects of standardized patient care pathways on clinical outcomes. Doctoral dissertation. The University of Tennessee, Knoxville. Retrieved from http://trace.tennessee.edu/utk_graddiss/3463

Trotter, F., \& Uhlman, D. (2011). Hacking healthcare: A guide to standards, workflows, and meaningful use. Sebastopol, CA: O’Reilly Media, Inc.

\section{BIBLIOGRAPHY}

Alo, M. (2013). Stress testing explained. Retrieved from Youtube video: https://www.youtube.com/watch?v=HbzRIkHpBsk

American College of Cardiology. (2018a). National cardiovascular data registry. Retrieved from https://www.ncdr.com/WebNCDR/docs/default-source/pinnacle-publicdocuments $/ 2018$ measure 006 registry.pdf?sfvrsn $=8$

American College of Cardiology. (2018b). PINNACLE registry. Retrieved from https://ncdr.com/WebNCDR/docs/pinnacle-resources/program-metrics.pdf?sfvrsn=2 
American Heart Association. (2018). Circulation. Retrieved from http://circ.ahajournals.org/content/circulationaha/early/2010/08/30/CIR.0b013e3181f5185b.full.p $\underline{\mathrm{df}}$

American Medical Association. (2018). Assets. Retrieved from https://assets.amaassn.org/resources/doc/pcpi/cadminisetjune06.pdf

Davidian, M. (2006). Inference for dynamic treatment regimes in two-stage clinical trials (and more generally). Retrieved from https://www4.stat.ncsu.edu/ davidian/dynamic.pdf

Davidian, M. (2014). An introduction to dynamic treatment regimes. Retrieved from https://www4.stat.ncsu.edu/ davidian/dtrwebinar.pdf

Davidian, M. (2016). Implementing precision medicine: Optimal treatment regimes and SMARTs. Retrieved from https://www4.stat.ncsu.edu/ davidian/pm_nhlbi.pdf

Murphy, S. A. (2003). Optimal dynamic treatment regimes. Journal of the Royal Statistical Society: Series B, JRSS-B 65(2), 331-355.

Murphy, S. A., van der Laan, M. J., Robins, J. M., and Conduct Problems Prevention Research Group. (2001). "Marginal mean models for dynamic regimes. Journal of the American Statistical Association 96(456), 1410-1423.

National Heart, Lung, and Blood Institute. (2006). Incidence and prevalence: 2006 chart book on cardiovascular and lung diseases. Bethesda, MD: National Institutes of Health. Retrieved from http://www.nhlbi.nih.gov/resources/docs/06 ip chtbk.pdf

Schulte, P. J., Tsiatis, A. A., Laber, E. B., and Davidian, M. (2014). Q-and A-learning methods for estimating optimal dynamic treatment regimes. Statistical science: a review journal of the Institute of Mathematical Statistics, 29(4), 640-641.

Zhang, B., Tsiatis, A. A., Laber, E. B., and Davidian, M. (2013). Robust estimation of optimal dynamic treatment regimes for sequential treatment decisions. Biometrika, 100(3), 681-694. 


\section{APPENDIX A. ICD-10 COMMON CARDIOVASCULAR DISEASE CODES}

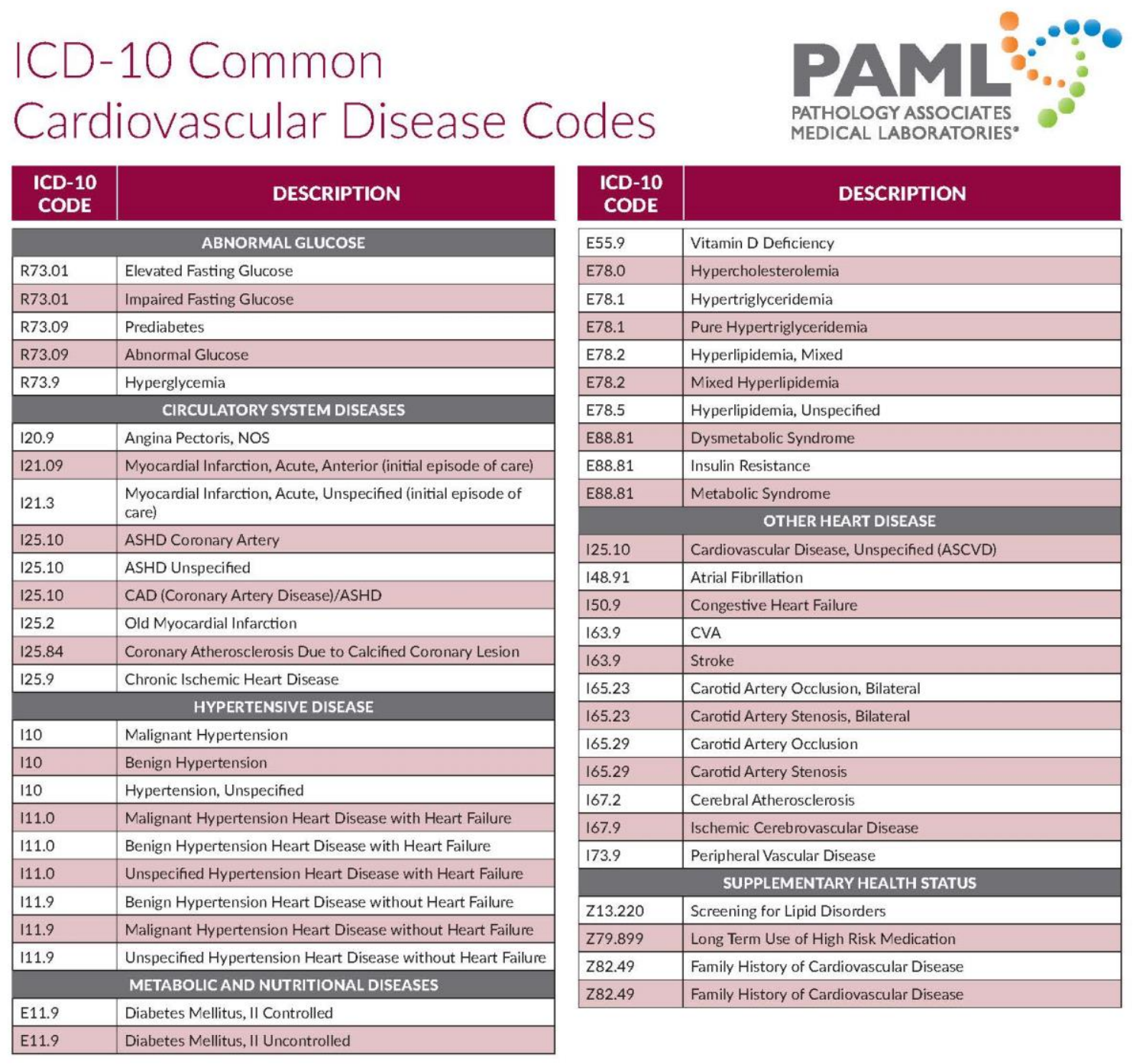

This list comprises only the most commonly used ICD-9/ICD-10 codes and is not intended to be all-inclusive. It is provided as an "at-a glance" tool to supplement the CMS LCD \& NCD Policies. ICD-9/ICD-10 codes must always be substantiated by patients' medical records.

The Diagnosis codes provided are based on CMS guideliries and are for informational purposes onily. Diagnosis coding is the sole resporsibility of the billing party. Please direct any questions regarding coding to the payer beirg billed. This list is intended to assist ordering providers in providing ICD-10 Diagriosis Codes as requifed by Medicare ond othier irsurers, It includes the most commonily found outpatient diagrio.

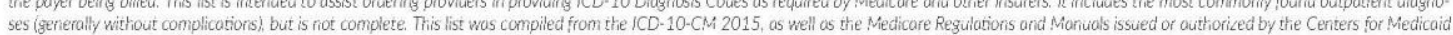
and Medicare Services. An ICD-10-CM book stiould be used as a complete reference. The ultimate responsibility for correct coding belorigs to the ordering provider.

Source: Pathology Associates Medical Laboratories. (n.d.). Retrieved from https://www.paml.com/sites/default/files/ICD-10_Cardiovascular_Codes-PAML.pdf 



\section{APPENDIX B. FIGURES REDRAWN FROM THE 2012 ACCF GUIDELINE FOR SIHD}

\section{Pathway map considerations:}

- The algorithms do not represent a comprehensive list of recommendations (see 2012 ACCF/AHA Guideline for all recommendations).

- For more information on ISHD refer to the 2012 ACCF/AHA Guideline.

- TSee 2012 ACCF/AHA Guideline Table 2 for short-term risk of death or nonfatal MI in patients with UA/NSTEMI.

- $\quad$ ‡CCTA is reasonable only for patients with intermediate probability of IHD.

\section{Pathway Map Legend:}

Color Guide:

Colors correspond to the class of recommendations in the 2012 ACCF/AHA Guideline Table 1.

(Green Box): Class I: benefit >>> risk according to the Classification of Recommendations and Level of Evidence and should be recommended.

(Yellow Box): Class Ila: benefit >> risk according to the Classification of Recommendations and Level of Evidence and it is reasonable to recommend.

Shape Guide:

\begin{tabular}{|c|c|c|c|}
\hline Required & Decision or assessment point & Exit pathway & Referral \\
\hline - - - Possible & Patient (disease) characteristics & Off-page reference & Wait time indicator point \\
\hline Intervention & Consultation with specialist & Patient path & \\
\hline
\end{tabular}

\section{Abbreviations:}

CCTA: computed coronary tomography angiography;

CMR: cardiac magnetic resonance;

ECG: electrocardiogram;

Echo: echocardiography;

IHD: ischemic heart disease;

MI: myocardial infarction;

MPI: myocardial perfusion imaging;

Pharm: pharmacological;

UA: unstable angina;

UA/NSTEMI: unstable angina/non-ST-elevation myocardial infarction.

Figure B-1. Pathway legend. 


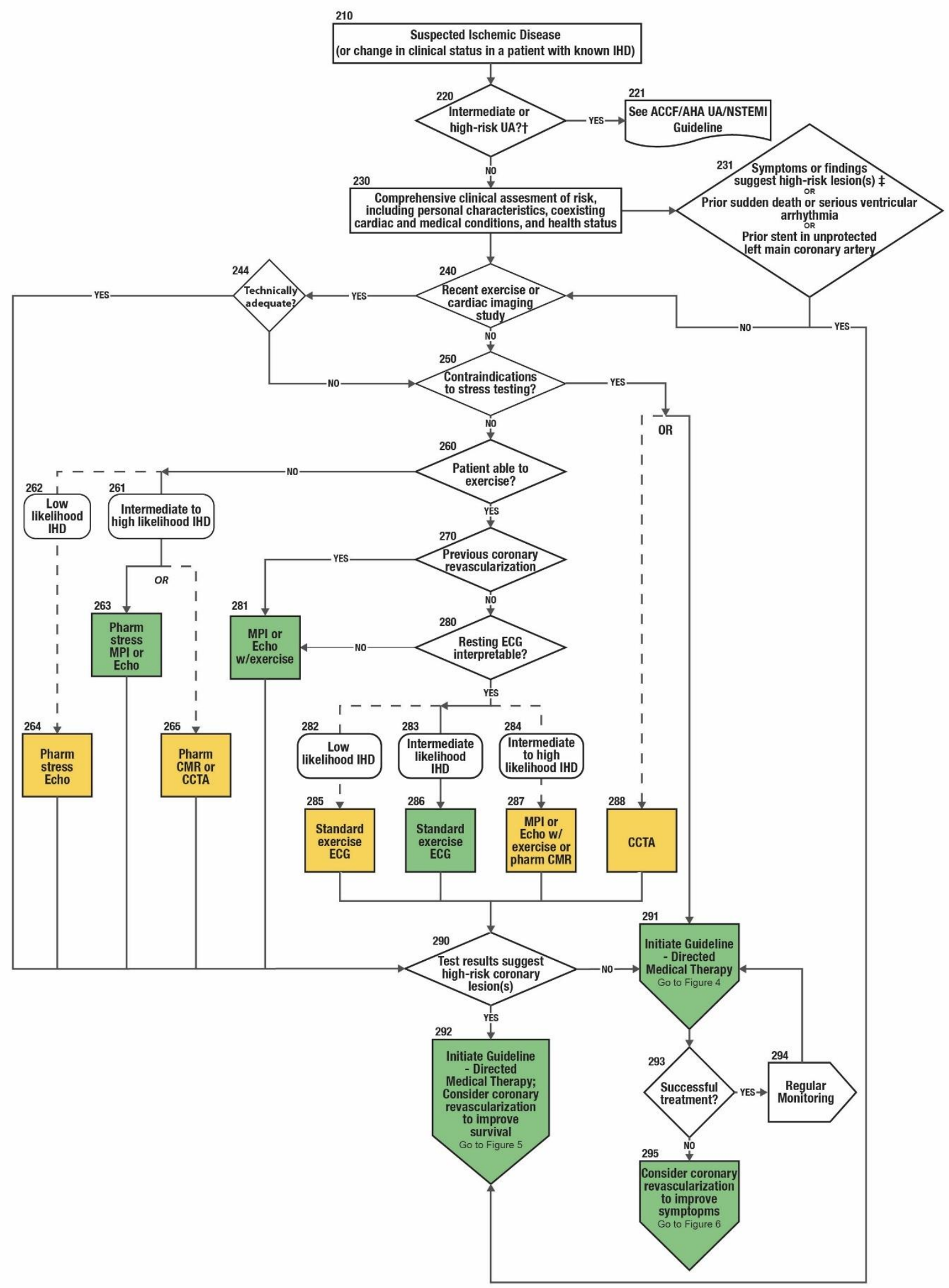

Figure B-2. Revised 2012 ACCF guideline for SIHD Figure 2 (Fihn et al. 2012). 


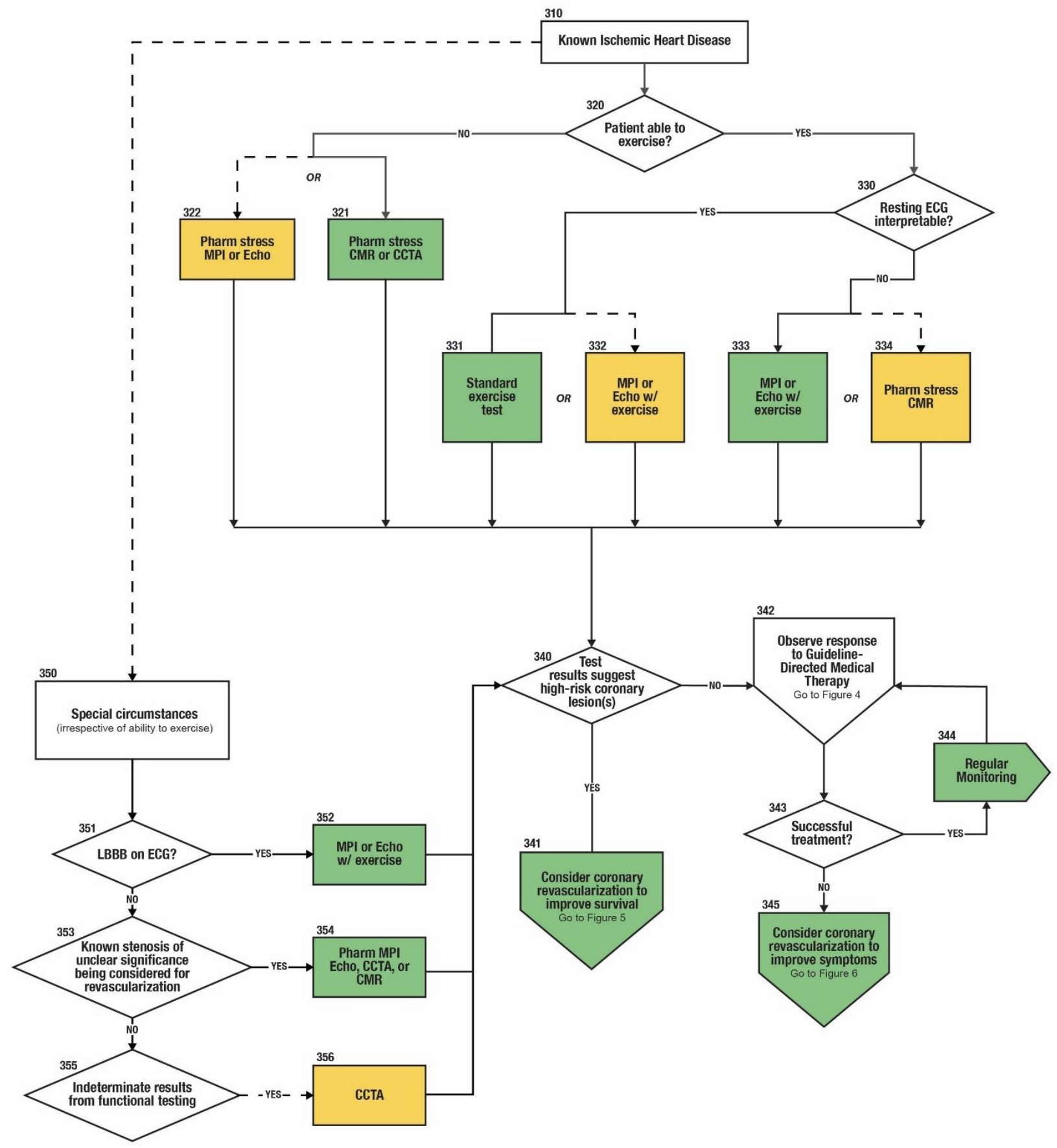

Figure B-3. Revised 2012 ACCF guideline for SIHD Figure 3 (Fihn et al. 2012). 


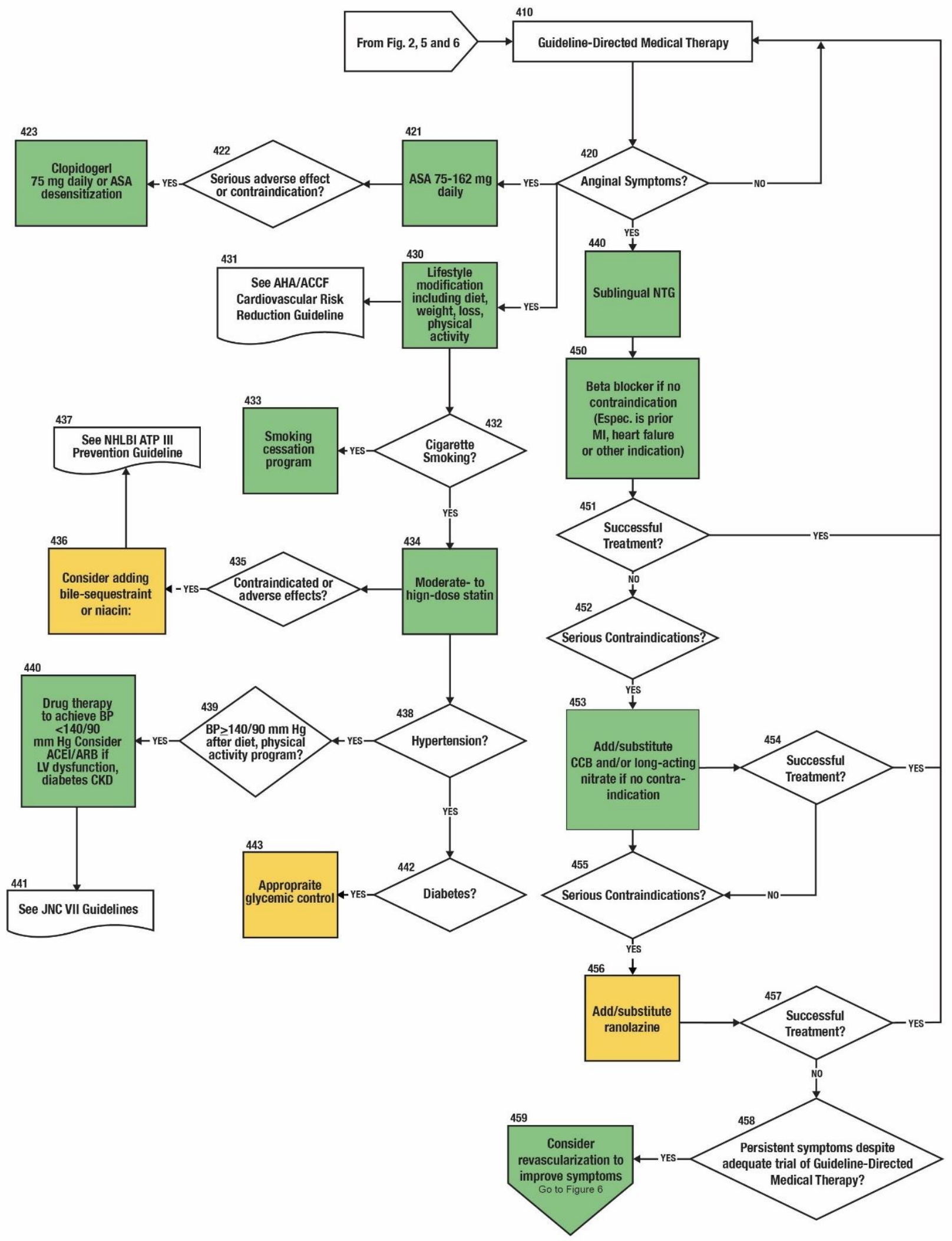

Figure B-4. Revised 2012 ACCF guideline for SIHD Figure 4 (Fihn et al. 2012). 


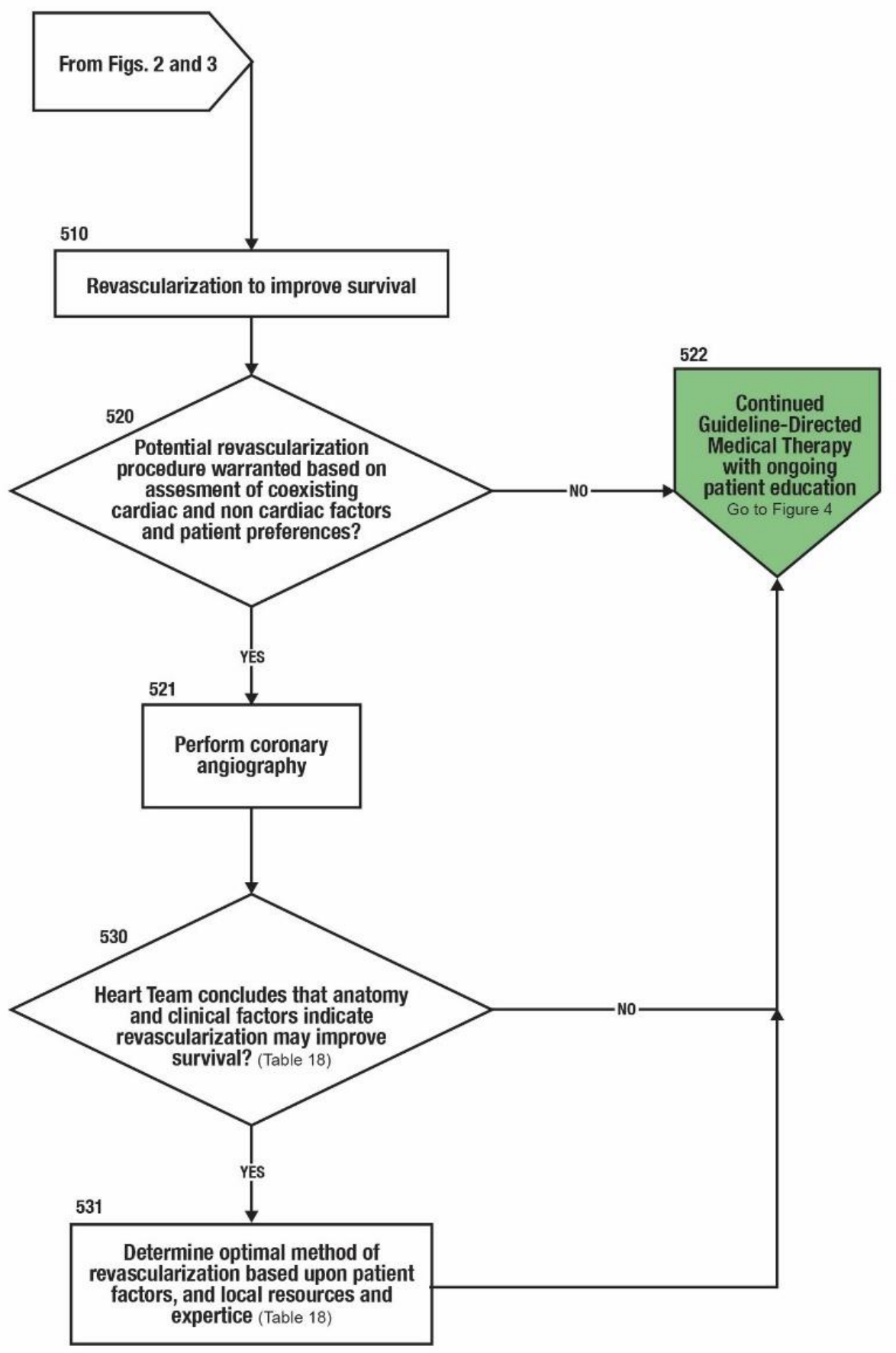

Figure B-5. Revised 2012 ACCF guideline for SIHD Figure 5 (Fihn et al. 2012). 


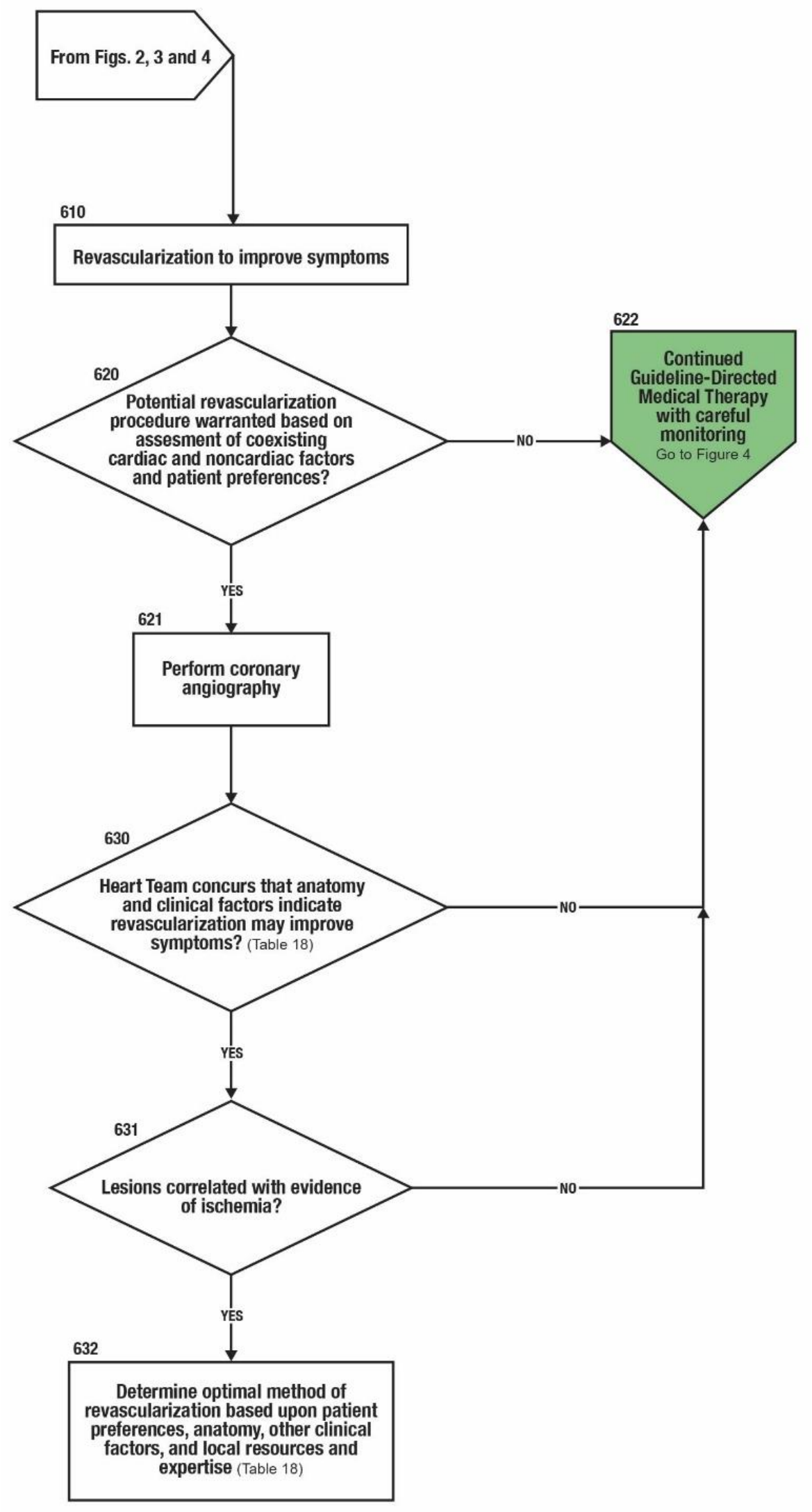

Figure B-6. Revised 2012 ACCF guideline for SIHD Figure 6 (Fihn et al. 2012). 


\section{APPENDIX C. RAW DATA}

Below is a sample subset of the raw data for bad aminophylline reactions to stress tests. The CPT codes from 30,569 office visits in 2017 were processed and aggregated into 10 groups using the following transformations:

- Administrative CPT codes were removed.

- All pharmacological stress agents (e.g., regadenoson, dobutamine, atropine) were collapsed into CPT code 93024.

- All echocardiograms were collapsed into CPT code 93350.

- All MPI modalities (e.g., single photon emission computed tomography, SPECT, and cardiac positron emission tomography, PET) were collapsed into CPT code 78452. Codes related to the nuclear tracing agent were removed if present.

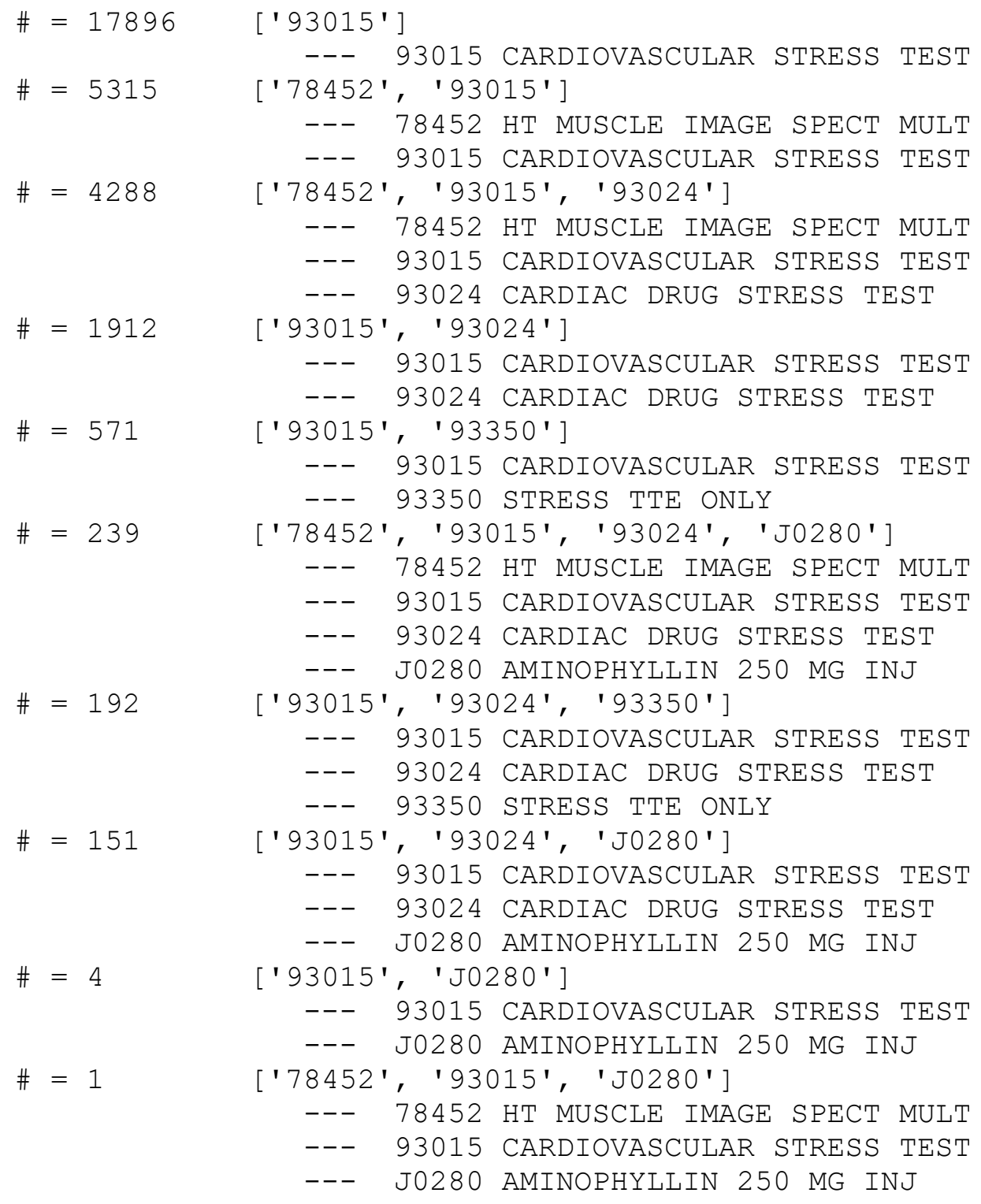

